\title{
Fertility Differences Between Migrants and Stayers in a Polygamous Context: Evidence from Senegal
}

\author{
Elisabeth K. Kraus ${ }^{1}$ (D) Amparo González-Ferrer ${ }^{2}$
}

Accepted: 26 December 2020 / Published online: 28 April 2021

(C) The Author(s) 2021

\begin{abstract}
This study takes a 'country-of-origin' or dissimilation perspective to compare the timing of births and completed fertility of international migrants and of those who stay at origin. In order to disentangle selection effects determining differential fertility behaviour of migrants, other mechanisms explaining migrant fertility (disruption, interrelation of events) are also examined. Furthermore, we take into consideration the prevalence of polygamy in Senegal to enhance our knowledge of migrant fertility in this specific context. For the empirical analysis, we use longitudinal data collected in the framework of the MAFE-Senegal project (Migrations between Africa and Europe), which includes retrospective life histories of non-migrants in Senegal and migrants in France, Italy and Spain. We estimate discrete time hazard models and Poisson regressions for male and female respondents separately to analyse the timing of first and higher-order births as well as completed fertility. The results show a strong disruptive effect of migration on childbearing probabilities for men and women, clearly related to the geographic separation of partners due to the out-migration of the man. Increased birth risks in the first year upon arrival could be observed for migrant women following their husbands to Europe, suggesting an interrelation of migration and fertility events. Regarding completed fertility, migrants have significantly fewer children by the age of 40 compared to their non-migrant counterparts, which among men is largely driven by a strong negative effect of polygamous migrants.
\end{abstract}

Keywords Migration $\cdot$ Fertility $\cdot$ Polygamy $\cdot$ Sub-Saharan Africa $\cdot$ MAFE

Elisabeth K. Kraus

elisabeth.kraus@bib.bund.de

Amparo González-Ferrer

amparo.gonzalez@cchs.csic.es

1 Federal Institute for Population Research, Wiesbaden, Germany

2 Spanish National Research Council (CSIC), Madrid, Spain 


\section{Introduction}

In 2013, about 540,400 Senegalese lived abroad, which corresponds to almost $4 \%$ of the Senegalese population. In the same year, the top five destination countries of Senegalese migrants were France, the Gambia, Italy, Spain and Mauritania (World Bank 2016). With a total fertility rate of 5.1 children per woman (ANSD 2014), fertility is high, placing the country at the intermediate stage of the fertility transition (Schoumaker 2019). Furthermore, almost one-quarter of married men in Senegal live in polygamous marriages, and nearly one-half of all married women have at least one co-wife (ANSD 2014). High rates of out-migration, high fertility levels and a relatively high prevalence of polygamy make Senegal an interesting case for studying the fertility behaviour of migrants: The separation of partners due to intercontinental long-distance migration to Europe is likely to have a major impact on the timing of births and completed fertility of men and women.

Research on international migration and fertility of sub-Saharan African migrants to Europe is scarce. The few studies that examine the fertility of African migrants in European destination areas do not take into consideration the fertility behaviour at origin but rather compare migrants' fertility to that of natives at destination (Devolder and Bueno García 2011; Toulemon 2004) or only look at migrants (Kraus 2019). One noteworthy exception is the article by Wolf and Mulder (2018), which analyses the reproductive behaviour of Ghanaian migrants in the Netherlands and the UK compared to stayers in Ghana. Furthermore, only few studies on migration and fertility deal with the issue of polygamy (Bledsoe 2004; Bledsoe et al. 2007; Bledsoe and Sow 2008). In other migration settings, scholarship on migrant fertility also mostly compares the fertility behaviour of migrants with that of natives at destination (González-Ferrer et al. 2017; Krapf and Wolf 2015; Kulu 2005; Milewski 2007). Few studies analyse the fertility of migrants compared to that of stayers at origin, taking a 'context-of-origin' or dissimilation perspective (FitzGerald 2012; Guveli et al. 2017; Guveli et al. 2016). This has been done for Mexico-US migration (Choi 2014; Frank and Heuveline 2005; Lindstrom and GiorguliSaucedo 2002, 2007; Massey and Mullan 1984; Parrado 2011) and Turkey-Germany migration (Baykara-Krumme and Milewski 2017; Guveli et al. 2016), for both of which bi- or multinational data from origin and destination areas are available.

Various mechanisms or hypotheses have been developed to describe and explain the link between migration and fertility (Andersson 2004; Kulu 2005; Kulu and GonzálezFerrer 2014; Milewski 2007; Milewski and Mussino 2018). Theoretically and methodologically, these explanations build on the assumption of monogamous partnerships, while polygamous unions are not considered. To fill this gap in current research on migrant fertility, we aim at answering the following research questions: What are the differences in fertility timing and quantum between international migrants and stayers at origin? How is the migration experience of male and female partners related to their fertility outcomes? And, finally, how is migrants' fertility shaped in a polygamous context of origin? We answer these questions by focusing on Senegalese migrants in Europe and their nonmigrant $^{1}$ counterparts at origin. We utilize data from the MAFE-Senegal project

\footnotetext{
${ }^{1}$ The terms 'non-migrant' and 'stayer' are used interchangeably throughout the article, both referring to individuals who remain in their country-of-origin, i.e. who did not migrate (yet).
} 
(Migrations between Africa and Europe), which collected longitudinal retrospective life histories in Senegal and in the major European destination countries: France, Italy and Spain.

The contributions of this study are twofold. First, most studies on migrant fertility concentrate on women only, neglecting entirely the location of the male partner. Few other studies include migrant men's migration trajectories or their socioeconomic characteristics and the impact on fertility (Guetto and Panichella 2013; Kraus 2019; Milewski 2007; Wolf 2016; Wolf and Mulder 2018). However, male and female migration and fertility trajectories tend to be 'coordinated and interdependent' and part of a joint household strategy (Lindstrom and Giorguli-Saucedo 2007, p. 827). Thus, besides the migration moves of the respondent, this article also pays attention to the whereabouts of the partner (or partners in polygamous unions). Second, the aspect of polygamy will be added to the standard explanations for migrant fertility.

\section{Background}

\section{Marriage, Polygamy and Fertility in Senegal}

In Senegal, the extended family is the basic social unit (Baizán et al. 2014). On average, a household consists of eight individuals (ANSD 2014), one of the largest household sizes in West Africa. This size is a result of both the extended multigenerational family structure forming the household, as well as the polygamous regime. As in many polygynous societies, marriage in Senegal is almost universal (Lardoux and Van de Walle 2003) and staying unmarried is seen as a 'secondary choice' (Antoine and Nanitelamio 1996, p. 130) and few Senegalese stay unmarried. In 2013, the mean age at first marriage was 22.4 for women (rural: 19.4, urban: 25.5) and 29.9 for men (rural: 27.7, urban: 31.9), indicating a significant age difference between spouses (ANSD 2014). A total of $23.1 \%$ of married men live in polygamous marriages, and $44.0 \%$ of all married women have at least one co-wife. On average, polygamous men have 2.6 wives. Polygamy is more widespread in rural areas $(39.8 \%)$ than in urban areas $(29.1 \%)$ and decreases with educational attainment, ranging from $24.1 \%$ for men and $47.1 \%$ for women among those with no formal education to $13.9 \%$ for men and $24.1 \%$ for women among those with superior educational attainment (ANSD 2014). Polygamy is only possible due to the significant age differences between spouses, especially between men and their second or higher-rank wives (Antoine 2006). Over time, the prevalence of polygamy seems to have declined 'with education and urbanization' (Bledsoe et al. 2007, p. 388). Divorce rates in Senegal are relatively high, especially in urban areas (Antoine and Nanitelamio 1996), but due to rapid remarriage and high levels of polygamy among the men, only 0.7 and $2.1 \%$ of the men and women, respectively, were divorced and single in 2013 (ANSD 2014).

Generally, marriages are arranged within the extended family and are often formed between cousins (Vives and Vazquez Silva 2016). After marriage, the first and potential other wives usually move in with their family-in-law to care for the elders, especially the mother-in-law (González-Ferrer et al. 2012). This does not necessarily mean, however, that the wife (wives) cohabits under the same roof with their husband, as it is not unusual that partners live in different places (Beauchemin 
et al. 2013; Lardoux and Van de Walle 2003), for example due to internal or international migration of the man. Separate residence, arranged marriages, polygamy and relatively large age differences between spouses are all factors that add up to a certain social distance between partners (González-Ferrer et al. 2012; Vives and Vazquez Silva 2016).

Fertility in Senegal is high, with 5.1 children per woman in 2013, with an important urban-rural divide (rural: 6.2, urban: 4.1; ANSD 2014). The high fertility levels are likely to be the result of 'the cultural desire for large families, the high infant mortality rate and the low use of modern contraceptive methods' (Bass and Sow 2006, p. 95). Women's fertility decreases with the number of co-wives, which is mainly the result of lowered frequency of intercourse and increased age of the husband when higher-rank wives enter the polygamous union (Lardoux and Van de Walle 2003). As in other subSaharan African countries, Senegalese fertility declines over time at a relatively slow pace, compared to other developing countries (Bongaarts 2016).

\section{Senegalese Migration to Europe: History and Family Migration Strategies}

Senegalese migration to France, as the former colonial power, essentially began in the early 1960s (Beauchemin et al. 2013). Early Senegalese migrants were recruited to join the French army, and later, many of them stayed to work in the automobile industry. In the 1970 s and 1980 s, economic migration to France became more difficult due to stricter immigration policies, and, consequently, migratory flows diversified and migrants also chose other European destinations. In the 1990s, Italy became the most important destination within Europe. From the end of the 1990s onwards, Spain also became an important receiving country for Senegalese migrants (Beauchemin et al. 2014).

Migration strategies of sub-Saharan African migrants in Europe changed over time. In the 1960s, Senegalese migrants to France were mainly young, male and single (Barou 2001). After spending several years at the destination and accumulating sufficient economic resources, migrant men started forming families in Senegal with one or several wives and children during regular visits at home. Once the migrants returned for good, they were in the advantaged position of being the head of a family with various polygamous unions and several children (Barou 2001). This migration practice of male migrants became more difficult when immigration policies at destination restricted and impeded these circular migration strategies. The possibility of reuniting with the wife/wives (and children) at the destination appeared as a new option in the late 1970s (Beauchemin et al. 2013). However, reunification at the destination was a 'sub-optimal choice' (Baizán et al. 2014) for several reasons.

First, Senegalese elders often opposed the practice of reunification at destination since they would lose a large part of the remittances sent by their sons from Europe, as well as the household help of their daughters-in-law (Baizán et al. 2014; GonzálezFerrer et al. 2012). Second, large and often polygamous Senegalese families encountered problems in Europe related to social integration and housing. Moreover, restrictive immigration policies prohibited the reunification of polygamous families (Baizán et al. 2014; Beauchemin et al. 2013) and polygamous men could lose their work and residence permits for having more than one wife. This led to a possible marginalization 
of additional wives and their children 'by divorcing her, whether in name or in fact, or sending her back home, even though she may have originally come quite lawfully under a French regime that allowed polygamy' (Bledsoe 2004, p. 103). The result was a circulation of young women, 'a slot dynamic [...]: a tendency to rotate multiple holders through a single position', resulting in high fertility rates during short time periods, as has been found for Gambians in Spain (Bledsoe and Sow 2008, pp. 11-12). Other studies using the same dataset as our study found that partners living in polygamous unions have significantly lower odds of reunifying with their partner at the destination (Baizán et al. 2014; Beauchemin et al. 2015). Thirdly, the normality of social distance and of spatial separation among couples prevalent in Senegalese society contributed to long-lasting transnational family arrangements (Vives and Vazquez Silva 2016), which are more prevalent than reunification at destination (Baizán et al. 2014). The migrants who, from the 1990s onwards, chose Italy and Spain as preferred European destinations, faced similar problems with regard to their family arrangements. Finally, the independent migration of Senegalese women to European destinations is an emerging, but still rather scarce, phenomenon (Toma and Vause 2013).

Another peculiarity of Senegalese couples in the context of international migration is that a relatively high share of unions is formed at a distance, meaning that the partners do not reside in the same country at the moment of union formation. These marriages are sealed rapidly during migrants' visits to Senegal and are negotiated between the two families or within the extended family (Mondain et al. 2009). According to Baizán et al. (2014), one-half of all Senegalese transnational partnerships were formed while the man already had migrated to Europe.

\section{Migration and Fertility: Theoretical Framework, Previous Empirical Evidence and Hypotheses}

Most studies on migration and fertility build on different hypotheses or explanations that describe and examine differences in fertility timing and quantum between migrants and the native population at the destination - such as adaptation, convergence or assimilation. In this study, however, we take a 'context-of-origin' or dissimilation perspective (FitzGerald 2012; Guveli et al. 2017; Guveli et al. 2016) by comparing the fertility behaviour of migrants with that of the non-mobile population at origin ('stayers'). This approach allows to disentangle dissimilation effects - i.e. 'how migrants dissimilate (become different from those whom they leave behind)' (FitzGerald 2012, p. 1726), also called 'homeland dissimilation' (FitzGerald 2012). The dissimilation perspective covers selection effects - i.e. that migrants are a (self-) selected group with characteristics associated with differential fertility behaviour compared to the overall origin population - as well as issues related to the migration process itself, namely fertility disruption due to migration and interrelation of several life course events.

\section{Selection}

The selection hypothesis argues that the fertility behaviour (timing and quantum) of migrants differs from that of non-migrants at origin due to the fact that migrants 
are not randomly selected from their population of origin. Migrants may be selected (or self-select) on observable characteristics, such as education and other socioeconomic factors (Adserà and Ferrer 2014), as well as on unobservable characteristics such as social mobility aspirations (Milewski 2010a), openness to innovation (Lindstrom and Giorguli-Saucedo 2002), high aspirations for children or family proneness (Kulu and González-Ferrer 2014; Lindstrom and GiorguliSaucedo 2007). Most previous studies on international migration and the fertility selection hypothesis cover Mexican migration to the USA (Lindstrom and Giorguli-Saucedo 2002, 2007), Turkish migration to Germany (Baykara-Krumme and Milewski 2017; Guveli et al. 2016) or one article on Ghanaian migration in Western Europe (Wolf and Mulder 2018), for which bi-national surveys sampling migrants and non-migrants at origin were conducted. A recent article compares Albanian, Moroccan and Ukrainian migrant women in Italy, Italian native women in Italy as well as non-migrant women at the respective countries of origin, merging different data sources (Impicciatore et al. 2020). Although researchers arrive at different conclusions, they agree that migrants are selected on observable and unobservable characteristics that influence their fertility behaviour, but the degree and the type of selection are ambiguous.

Intercontinental migration from sub-Saharan Africa to Europe involves overcoming long geographic distances, implying a relatively high amount of financial resources and knowledge. Thus, the poorest ones are not those who manage migrating from Senegal to Europe but rather those with a certain educational and financial level (Shaw 2007; van Dalen et al. 2005). Using the same dataset as this paper, González-Ferrer et al. (2014) have shown that Senegalese migrants in Europe are a positively selected group of their population of origin in terms of socioeconomic status (González-Ferrer et al. 2014) and Toma and Vause (2013) have found that migrant women are more highly educated than their non-migrant counterparts and that this positive selectivity holds true for both independent female migrants as well as partner-related migration. Furthermore, in patriarchal societies such as Senegal, where women face social control by their extended family, highly educated women are more likely to reunify with their partners in European destination countries, while less educated women more often stay behind in the country-of-origin (Baizán et al. 2014; Beauchemin et al. 2015). Highly educated men are more likely to reunify with their wives in Europe than in Senegal (Baizán et al. 2014). Hence, men and women who live with their partner in Europe tend to be more highly educated compared to men and women who are separated from their partner due to migration, as well as stayers at origin.

Educational selectivity might explain — at least partly - the differential fertility behaviour of migrants compared to stayers. In most developing countries, poorer, less educated and rural women have higher and earlier fertility patterns than their wealthier, more educated and urban counterparts (Bongaarts 2003; Castro-Martín and Juarez 1995; Schoumaker 2004; Weinberger 1987). For Senegal, Marchetta and Sahn (2015) found a strong delaying effect of women's education on the age at first child, operating mainly through a later entry into marriage (Marchetta and Sahn 2015). Within partnerships, the effect of the wife's education is more influential for couples' fertility behaviour (timing and quantum) than the influence of the husband's educational level (Jejeebhoy 1995). Therefore, as migrants 
to Europe tend to be positively selected in terms of their socioeconomic status, we expect that, controlling for individual socioeconomic characteristics, fertility differentials (timing and quantum) between migrant and non-migrant men and women should diminish (H1: Selection and fertility timing and completed fertility).

\section{Fertility Disruption}

Other explanations that disentangle differences in fertility between migrants and non-migrants describe diverging fertility patterns of migrants linked to the migration process itself. The disruption hypothesis states that birth timing and birth spacing of migrants may be disrupted or delayed during the time shortly before and after the migration move due to disruptive factors inherent to the migration process, such as economic and psychological stress or the spatial separation of spouses (Kulu 2005). Especially, the geographic separation of partners due to migration is likely to have a temporary disruptive effect on men and women's fertility calendar due to reduced exposure to conception, which might be particularly important in origin countries with relatively high fertility rates, such as Senegal, and long-distance migration flows, where mutual visits are difficult. A short-term disruptive effect of couple separations on birth probabilities has been found for Mexican migrants to the USA (Lindstrom and Giorguli-Saucedo 2002, 2007; Massey and Mullan 1984), as well as in the context of sub-Saharan African migration, e.g. intercontinental and internal migration in Mozambique (Agadjanian et al. 2011), or internal migration in Ghana (Chattopadhyay et al. 2006). To sum up, long-lasting transnational family arrangements are often the preferred option of Senegalese families due to strict visa requirements and restrictive immigration policies in European destination countries as well as the culturerelated preferences pointed out above. Furthermore, long geographic distances associated with high travel expenses (González-Ferrer et al. 2014) make circular migration strategies difficult. For all these reasons, Senegalese partners experience prolonged separations from each other. Therefore, our expectation regarding fertility disruption is that women and men who are spatially separated from their partner-or partners in the case of polygamous men-due to out-migration experience a disruption in childbearing and, accordingly, have lower birth probabilities compared to non-migrant women and men at origin (H2: Disruption and fertility timing).

Fertility disruption due to the separation of partners primarily influences birth timing; however, in the long run, completed fertility may also be affected, if partners are not able to make up for the lost reproductive time caused by their spatial separation. If migration episodes are short or if they coincide with nonfecund periods, couples are likely to catch up with their non-migrant counterparts in terms of the number of children, as has been found for the case of Mexican migration to the USA (Lindstrom and Giorguli-Saucedo 2002). In Senegal, however, separations related to the migration to Europe of one partner are longer-term arrangements and thus, fertility recovery might be more difficult compared to migration settings where spousal separation is rather short-term. Baizán et al. (2014) found that 10 years after migration-related separation, only approximately 
$40 \%$ of the migrants had (re)unified with their partner either at destination or at origin. This means that the conception of more children is restricted to visits of the migrant partner at origin or the non-migrant partner at the destination. Hence, concerning disruption and completed fertility, we hypothesize that women and men who are either themselves a migrant and/or have a migrant partner show lower completed fertility compared to non-migrant men and women at origin (H3: Disruption and completed fertility).

Finally, research dealing systematically with the impact of international migration processes on fertility behaviour in polygamous unions is scarce (exceptions include Bledsoe 2004; Bledsoe et al. 2007; Bledsoe and Sow 2008; Sargent and Cordell 2003). Migrant men with multiple wives at the same time may be spatially separated from them at the same time; thus, the disruptive effect of migration on fertility should be stronger. We thus expect that for polygamous men the depressive effect of migration on fertility timing and completed fertility should be stronger compared to monogamous migrant men (H4: Disruption and polygamy).

\section{Interrelation of Migration, Union Formation and Fertility}

The interrelation of events hypothesis argues that higher-birth risks immediately after migration can be seen as the coincidence of several life events-migration and marriage-taking place at the same time (Mulder and Wagner 1993) and thereby temporarily resulting in higher first-birth probabilities compared to natives at destination and non-migrants at origin (Andersson 2004; Lindstrom and Giorguli-Saucedo 2007; Milewski 2007). In the case of marriage migration, most studies agree on the fact that marriage and migration are interrelated events and that (mostly female) marriage migrants have an accelerated transition to a first child upon arrival at destination (Andersson 2004; Milewski 2007; Nedoluzhko and Agadjanian 2010; Nedoluzhko and Andersson 2007). While this refers mostly to first-birth probabilities, the timing of second and higher-order births may also be affected after the reunification of partners. The migration of the second spouse (usually the woman) to join the partner at destination may be interpreted as a 'reformation of an old household under new circumstances' (Milewski 2010b, p. 303 ) and thus result in higher higher-order birth probabilities compared to natives at destination or stayers at origin, also called 'arrival effect' (Milewski 2010b). It has also been observed that disrupted fertility behaviour before the migration move was recovered by higher childbearing rates shortly after the move, known as 'catching-up behaviour' (Goldstein and Goldstein 1981; Milewski 2007). Using the same data as this study does, Kraus (2019) graphically shows that female Senegalese migrants experience one or several first or higher-order births in the years following their migration to Europe, also indicating an arrival effect. Similarly, after a marriage formed at a distance, the woman may follow her husband to the destination country immediately or after some time and, once at the destination, experience a quick transition to a first or subsequent child. We expect that Senegalese women have higher birth probabilities in the years immediately after arriving at their destination compared to non-migrant women at origin (H5: Interrelation of events and fertility timing). 


\section{Data and Methods}

\section{Data: The MAFE-Senegal Survey}

Properly analysing whether migrants and non-migrants differ in their fertility behaviour has several data requirements. First, a dataset including information on migrants as well as on stayers at origin is needed. Therefore, a transnational sample is required that covers data both on individuals that migrated as well as individuals that never left the country of origin. Second, since we focus on men and women, the data should provide information on migration and fertility histories of both sexes. Third, we are interested in the temporal ordering of migration and childbearing events. Hence, a longitudinal time-varying dataset is required. Fourth, we are not only interested in the time-varying migration status of the respondents but also of their partners.

The MAFE survey (Migrations between Africa and Europe ${ }^{2}$ ) is one of the few datasets that fulfils all four criteria. In the framework of this project, longitudinal life-history data were collected in sub-Saharan African origin countries and in major European destination countries. For the Senegalese part of the project, about 200 current Senegalese migrants were interviewed in three European destination countries - France, Italy and Spain — throughout 2008. Furthermore, some 1000 individuals (non-migrants, returnees and migrants' spouses) were interviewed in Senegal. In Spain, a second round of the survey was conducted in 2011 (Migraciones entre Senegal y España (MESE)), adding 405 individuals to the original sample of Senegalese migrants in Spain. ${ }^{3}$ In total, the dataset contains life histories of 2073 men and women.

In each country, a different sampling strategy was applied to select the respondents. In Spain, the municipal population register (Padrón) served as a national sampling frame for drawing a random sample of undocumented and documented Senegalese migrants. Since in France and Italy no such sampling frame exists, a nonprobabilistic quota sampling technique was used. In Senegal, a stratified random sample was drawn from households and individuals living in the region of the capital city Dakar. The fact that non-migrants were sampled only in Dakar might bias the results, insofar as the migrants interviewed in Europe originate from all over Senegal. The capital region is different from more rural Senegalese areas in socioeconomic and demographic terms, as well as in its gender norms, resulting in differential fertility behaviour (TFR in urban areas 4.1 and in rural areas 6.2

\footnotetext{
${ }^{2}$ The MAFE project is coordinated by INED (C. Beauchemin) in partnership with the Université catholique de Louvain (B. Schoumaker), Maastricht University (V. Mazzucato), the Université Cheikh Anta Diop (P. Sakho), the Université de Kinshasa (J. Mangalu), the University of Ghana (P. Quartey), the Universitat Pompeu Fabra (P. Baizán), the Consejo Superior de Investigaciones Científicas (A. González-Ferrer), the Forum Internazionale ed. Europeo di Ricerche sull'Immigrazione (E. Castagnone) and the University of Sussex (R. Black). The MAFE project has received funding from the European Community's Seventh Framework Programme under grant agreement 217206. The MAFE-Senegal survey was conducted with the financial support of INED, the Agence Nationale de la Recherche (France), the Région Ile de France and the FSP programme 'International Migrations, territorial reorganizations and development of the countries of the South'. For more information, see https://mafeproject.site.ined.fr/en/.

${ }^{3}$ Additional analyses showed that the results across the two Spanish samples, apart from some minor differences, were substantively the same.
} 
children per woman; ANSD 2014). Since fertility is lower in Dakar than in other areas, this inconsistency should not be problematic for the analyses but rather strengthen the findings. The samples across all countries were stratified by age and sex; men and women each represented $50 \%$ of all surveyed individuals in each country, and half of the individuals of both genders were aged between 25 and 40, the other half between 41 and 75 (Beauchemin and González-Ferrer 2011). Our descriptive results are weighted to account for the different sampling procedures employed across different countries (for a detailed description of the weighting strategies, see Schoumaker and Mezger 2013).

The dataset includes time-varying residential and migration histories as well as information on childbearing and union formation of the interviewee. Moreover, the respondent also provided information on their past and current partners (educational attainment, socioeconomic and civil status at the time of the survey, country of birth, nationality and migrations) and complete histories could be reconstructed including exact information on the children born and the migratory movements of both partners.

\section{Analytical Approach}

The empirical section is divided into two parts; the first covers the timing of childbearing and how migration contributes to short-term fertility differentials between migrant and non-migrant men and women and the second examines completed fertility and the long-term differences between these groups.

From the initial MAFE-Senegal sample $(N=2,073), 4$ women were dropped because they indicated having two partners simultaneously. For the first part of the empirical analysis on fertility timing, the data were arranged as a person-year dataset. The annual histories begin at the age of 15 and end at the age of 45 for women and 60 for men or the year of the survey in 2008. The second data collection round in Spain was also limited to 2008; thus, observations for 20092011 were dropped. We opted for different age thresholds for men and women since men are able to have children up to higher ages and age differences between partners are relatively high in Senegal (ANSD 2014; Antoine and Nanitelamio 1996; Marchetta and Sahn 2015). Furthermore, only person-years spent within a union are included in the analysis, as childbearing out of the union is relatively rare in Senegal (first births out of union: women $N=40$, men $N=47$ ). Marriages as well as consensual unions are considered, although most unions are marriages. The final dataset consists of 11,750 person-years for women and 9,212 person-years for men (3,852 and 3,648 person-years for first-birth analyses), corresponding to 920 women and 778 men.

We employ discrete time hazard models with repeated events to predict the instantaneous hazard that an event (birth) will occur during a person-year (Box-Steffensmeier and Zorn 2002). For the analysis of first-birth risks, individuals leave the risk set once the event has occurred. The dependent variable is coded 0 when no birth occurs during a person-year and is coded 1 if a child is born. Standard errors are clustered on the individual level.

Table 5 (women) and Table 6 (men) in the appendix provide the descriptive sample characteristics used for the analyses of fertility timing by type of time-varying migration status of the respondent. The main independent variable is the time-varying 
residence of the partners. ${ }^{4}$ This categorical variable covers all migration stays of the respondent and his/her partner(s) of at least 1 year in duration and has four possible outcomes: 'both (all) partners in Senegal'; '(at least one) woman in Senegal, man in France, Italy or Spain'; 'both (all) partners in France, Italy or Spain' and 'other', which covers person-years in which one or both partners were in another country (i.e. none of the four survey countries, including mainly stays in neighbouring African countries). ${ }^{6}$ The category for partners being together in Senegal includes respondents and partners that never migrated as well as migrants before-or after, for return migrants - their migration. Since the survey only provides information on a yearly basis, we opted for lagging this variable by 1 year $(\mathrm{t}-1)$ in order to ensure the temporal ordering of migration and childbearing events. Assuming that pregnancy takes 9 months, a 1year lag seems an appropriate time interval. Another migration-related variable accounts for the duration of stay in France, Italy or Spain of the respondent ('arrival year', '+ 1 year', '+ 2 years', '+ 3 years', '4+ years/non-migrant'), which is also lagged one year.

To account for the sociodemographic selection of migrants, a variable of the combined education of the partners is included. This variable has four possible outcomes: 'both (all) primary', '(at least one) woman secondary/man primary', '(at least one) woman primary/man secondary or 'both (all) secondary'. We also account for whether the respondent was economically active in the previous year as well as for the lagged financial situation of the household regarding the purchase of basic goods, covering the categories 'less than sufficient' and 'sufficient or better'.

Furthermore, we include several dichotomous partnership-related covariates: Cowife in union, in the models for women, indicating whether the woman has at least one co-wife within the current partnership (versus not having a co-wife), and polygamous union, in the models for men, indicating whether the man has several wives simultaneously (versus only one wife). Fertility-related variables are the time since union formation/last birth, also serving as process time for the event history analyses. Moreover, in the models on higher-order births, we control for parity, which accounts for the birth number, ranging from 'parity 1' to 'parity 6+'. Furthermore, several demographic control variables were included in the models: Urban, to control for rural-urban differences in fertility and migration patterns, and measuring whether the respondent was born in one of the ten largest cities of Senegal. Religious affiliation is controlled for, distinguishing between the major Muslim brotherhoods, 'Tidiane' and 'Mouride' and 'other Muslim' branches, as well as the category 'other', which includes Christians and other religious affiliations. Furthermore, we control for birth cohort ('before 1965', '1965 and after') and age in age groups (women: '15-24', '25-34', '35-45; men: '15-24', '25-34', '35-44, '45-60').

\footnotetext{
${ }^{4}$ For male respondents, the MAFE data provide information on his past and current partners of all (simultaneous) partnerships. For female respondents, the data also give information on all her past and current partners and on whether or not there was a co-wife in the partnership. About these co-wives, however, no demographic or socioeconomic characteristics were collected.

${ }^{5}$ Terms in brackets refer to men in polygamous unions.

${ }^{6}$ Unfortunately, the number of person-years with the woman residing in Europe and the man residing in Senegal was too small for a separate category. This constellation was added to the 'other' category.
} 
Completed fertility of women and men was predicted using a reduced sample, including only respondents aged 40 and older ${ }^{7}$ at the survey and who ever had been in a partnership up to this age. The resulting sample covers 426 women and 450 men. The dependent variable is a measure for the number of children born up to this age and ranges from 0 to 14 , with a weighted mean of 5.1 for women and 4.1 for men. As this variable is count data, Poisson regression with robust standard errors to control for mild violations of the equidispersion assumption is used (Cameron and Trivedi 2009). The main independent variable accounts for the migration experience of the respondent and their partner(s) up to the age of 40 and has four possible outcomes for women: 'both (all) non-migrants', 'woman ever migrant in France, Italy or Spain, man non-migrant', 'woman non-migrant, man ever migrant in France, Italy or Spain' and 'both (all) ever migrants in France, Italy or Spain'. For men, only three categories were distinguished since the category 'woman migrant, man non-migrant' was not observed in the data on male respondents. Other covariates are co-wife in union (in the models for women), polygamous union (in the models for men), education of the partners, birth cohort, urban and religious affiliation, with the same categories as in the models for fertility timing.

\section{Results}

\section{Multivariate Results on Fertility Timing}

Models W1-W6 in Table 1 (women) and models M1-M6 in Table 2 (men) present the estimates for the discrete time hazard models of the transition to a (first) child according to the time-varying residence of the respondent and their partner(s), controlling for a range of other covariates. Regarding the socioeconomic selectivity of migrants, we expected that fertility differentials between migrant and non-migrant men and women would diminish once socioeconomic characteristics were controlled for (H1: Selection and fertility timing and completed fertility). In order to test this, we applied a stepwise approach; in models W2 and W4 for women and models M2 and M4 for men, several socioeconomic measures were added. However, the differences between current nonmigrants at origin and current migrants to France, Italy or Spain remain when adding the lagged educational attainment of the partners, labour force status of the respondent and the financial situation of the household. This holds for women and men as well as for first and higher-order birth transitions. Nevertheless, education is an important predictor of birth probabilities; women and men with secondary education have lower odds of a birth compared to their less-educated counterparts, which is in line with previous findings. Furthermore, men who were economically active in the previous year have a significantly higher probability of a first or higher-order birth in the following year compared to men who were not working. Women, on the contrary, have a lower probability of a higher-order birth if they worked in the previous year. Finally, having sufficient financial resources to purchase basic goods is positively associated with increased higher-birth probabilities, while this relationship is the opposite for first births. Stable economic conditions seem crucial to afford larger families.

\footnotetext{
${ }^{7}$ A higher age limit for men would have resulted in a sample too small for the regressions models.
} 
Table 1 Women: Discrete-time hazard models predicting a first/higher-order birth in given year (odds ratios)

\begin{tabular}{|c|c|c|c|c|c|c|c|}
\hline & & $\begin{array}{l}1^{\text {st }} \text { birth } \\
\text { (W1) }\end{array}$ & $\begin{array}{l}1^{\text {st }} \text { birth } \\
(\mathrm{W} 2)\end{array}$ & $\begin{array}{l}1^{\text {st }} \text { birth } \\
\text { (W3) }\end{array}$ & $\begin{array}{l}2+\text { births } \\
\text { (W4) }\end{array}$ & $\begin{array}{l}2+\text { births } \\
\text { (W5) }\end{array}$ & $\begin{array}{l}2+\text { births } \\
\text { (W6) }\end{array}$ \\
\hline $\begin{array}{l}\text { Time since union } \\
\text { formation/last } \\
\text { birth }\end{array}$ & & $0.90 * * *(0.01)$ & $0.91 * * *(0.01)$ & $0.91 * * *(0.01)$ & $0.96 * * *(0.01)$ & $0.96 * * *(0.01)$ & $0.96^{* * * *}(0.01)$ \\
\hline \multirow[t]{6}{*}{ Parity } & 1 & & & & Ref. & Ref. & Ref. \\
\hline & 2 & & & & $0.88+(0.06)$ & $0.86 *(0.06)$ & $0.86 *(0.06)$ \\
\hline & 3 & & & & $0.85 *(0.06)$ & $0.81 * *(0.06)$ & $0.81 * *(0.06)$ \\
\hline & 4 & & & & $0.75 * *(0.07)$ & $0.70 * * *(0.06)$ & $0.70 * * *(0.06)$ \\
\hline & 5 & & & & $0.94(0.10)$ & $0.86(0.09)$ & $0.86(0.09)$ \\
\hline & $6+$ & & & & $0.95(0.09)$ & $0.84+(0.08)$ & $0.84+(0.08)$ \\
\hline \multirow[t]{2}{*}{ Urban } & No & Ref. & Ref. & Ref. & Ref. & Ref. & Ref. \\
\hline & Yes & $1.09(0.10)$ & $1.10(0.10)$ & $1.10(0.10)$ & $0.85 * *(0.04)$ & $0.91+(0.05)$ & $0.91+(0.05)$ \\
\hline \multirow{4}{*}{$\begin{array}{l}\text { Religious } \\
\quad \text { affiliation }\end{array}$} & Tidiane & Ref. & Ref. & Ref. & Ref. & Ref. & Ref. \\
\hline & Mouride & $0.71 * * *(0.07)$ & $0.70 * * *(0.07)$ & $0.71 * * *(0.07)$ & $0.90+(0.05)$ & $0.91(0.05)$ & $0.91+(0.05)$ \\
\hline & Other Muslim & $0.89(0.12)$ & $0.91(0.12)$ & $0.90(0.12)$ & $1.07(0.09)$ & $1.10(0.09)$ & $1.10(0.09)$ \\
\hline & Other & $0.63 *(0.12)$ & $0.63^{*}(0.12)$ & $0.65^{*}(0.12)$ & $0.77 *(0.08)$ & $0.80 *(0.08)$ & $0.79 *(0.08)$ \\
\hline \multirow[t]{2}{*}{ Birth cohort } & Before 1965 & Ref. & Ref. & Ref. & Ref. & Ref. & Ref. \\
\hline & 1965 and after & $0.96(0.09)$ & $0.98(0.10)$ & $0.97(0.10)$ & $0.79 * * *(0.04)$ & $0.79 * * *(0.04)$ & $0.79^{* * *}(0.04)$ \\
\hline \multirow[t]{3}{*}{ Age } & $15-24$ & Ref. & Ref. & Ref. & Ref. & Ref. & Ref. \\
\hline & $25-34$ & $0.97(0.10)$ & $1.02(0.10)$ & $1.03(0.10)$ & $0.87 *(0.05)$ & $0.93(0.05)$ & $0.93(0.05)$ \\
\hline & $35-45$ & $0.57 *(0.15)$ & $0.61+(0.17)$ & $0.62+(0.17)$ & $0.40 * * *(0.04)$ & $0.45^{* * *}(0.04)$ & $0.46^{* * * *}(0.04)$ \\
\hline \multirow{4}{*}{$\begin{array}{l}\text { Residence of } \\
\text { partners, } \\
\text { combined }\end{array}$} & Both SN & Ref. & Ref. & Ref. & Ref. & Ref. & Ref. \\
\hline & $\begin{array}{c}\text { Woman SN, } \\
\text { man FIS }\end{array}$ & $0.62 * * *(0.09)$ & $0.60 * * *(0.09)$ & $0.60 * * *(0.09)$ & $0.62 * * *(0.05)$ & $0.61 * * *(0.05)$ & $0.61^{* * * *}(0.05)$ \\
\hline & Both FIS & $1.45^{*}(0.23)$ & $1.50 * *(0.23)$ & $1.34(0.27)$ & $0.75 * * *(0.05)$ & $0.75 * * *(0.05)$ & $0.71 * * *(0.06)$ \\
\hline & Other & $0.34 * * *(0.04)$ & $0.33^{* * *}(0.04)$ & $0.33^{* * * *}(0.04)$ & $0.70 * * *(0.06)$ & $0.69^{* * *}(0.06)$ & $0.68 * * *(0.06)$ \\
\hline \multirow[t]{2}{*}{ Co-wife in union } & No & Ref. & Ref. & Ref. & Ref. & Ref. & Ref. \\
\hline & Yes & $1.16(0.12)$ & $1.13(0.12)$ & $1.12(0.12)$ & $1.05(0.06)$ & $1.00(0.05)$ & $1.00(0.05)$ \\
\hline \multirow{4}{*}{$\begin{array}{l}\text { Education } \\
\text { partners, } \\
\text { combined }\end{array}$} & Both primary & & Ref. & Ref. & & Ref. & Ref. \\
\hline & $\begin{array}{l}\text { Woman } \\
\text { secondary, } \\
\text { man } \\
\text { primary }\end{array}$ & & $0.83(0.12)$ & $0.83(0.12)$ & & $0.69 * * *(0.06)$ & $0.69^{* * * *}(0.06)$ \\
\hline & $\begin{array}{l}\text { Woman } \\
\text { primary, } \\
\text { man } \\
\text { secondary }\end{array}$ & & $0.94(0.11)$ & $0.95(0.11)$ & & $0.92(0.06)$ & $0.91(0.06)$ \\
\hline & Both secondary & & $0.76^{*}(0.08)$ & $0.76^{*}(0.08)$ & & $0.73 * * *(0.05)$ & $0.73 * * *(0.05)$ \\
\hline \multirow{2}{*}{$\begin{array}{l}\text { Economically } \\
\text { active }\end{array}$} & No & & Ref. & Ref. & & Ref. & Ref. \\
\hline & Yes & & $1.00(0.09)$ & $1.03(0.09)$ & & $0.87 *(0.05)$ & $0.87 *(0.05)$ \\
\hline \multirow{2}{*}{$\begin{array}{l}\text { Financial } \\
\text { situation } \\
\text { household }\end{array}$} & $\begin{array}{l}\text { Less than } \\
\text { sufficient }\end{array}$ & & Ref. & Ref. & & Ref. & Ref. \\
\hline & $\begin{array}{l}\text { Sufficient } \\
\text { or better }\end{array}$ & & $0.89(0.09)$ & $0.90(0.09)$ & & $1.12 *(0.06)$ & $1.12 *(0.06)$ \\
\hline \multirow[t]{5}{*}{ Duration in FIS } & $\begin{array}{l}4+\text { years / } \\
\text { non-migrant }\end{array}$ & & & Ref. & & & Ref. \\
\hline & Arrival year & & & $2.07 * *(0.51)$ & & & $1.72 * *(0.32)$ \\
\hline & +1 year & & & $1.00(0.34)$ & & & $1.03(0.20)$ \\
\hline & +2 years & & & $0.47+(0.19)$ & & & $1.11(0.21)$ \\
\hline & +3 years & & & $0.76(0.31)$ & & & $0.83(0.18)$ \\
\hline$N$ (person-years) & & 3852 & 3852 & 3852 & 11,750 & 11,750 & 11,750 \\
\hline
\end{tabular}

Data: MAFE-MESE Biographic Survey (2008/2011), unweighted

$+p<0.1, * p<0.05, * * p<0.01, * * * p<0.001$; exponentiated coefficients; standard errors in parentheses; missing values in the independent variables are included in the models but results are not displayed; $S N=$ Senegal, FIS=France, Italy or Spain 
Table 2 Men: Discrete-time hazard models predicting a first/higher-order birth in given year (odds ratios)

\begin{tabular}{|c|c|c|c|c|c|c|c|}
\hline & & $\begin{array}{l}1^{\text {st }} \text { birth } \\
\text { (M1) }\end{array}$ & $\begin{array}{l}1^{\text {st }} \text { birth } \\
\text { (M2) }\end{array}$ & $\begin{array}{l}1^{\text {st }} \text { birth } \\
\text { (M3) }\end{array}$ & $\begin{array}{l}2+\text { births } \\
\text { (M4) }\end{array}$ & $\begin{array}{l}2+\text { births } \\
\text { (M5) }\end{array}$ & $\begin{array}{l}2+\text { births } \\
\text { (M6) }\end{array}$ \\
\hline \multirow{7}{*}{$\begin{array}{l}\text { Time since union } \\
\text { formation/last } \\
\text { birth Parity }\end{array}$} & & $0.92 * * *(0.01)$ & $0.92 * * *(0.01)$ & $0.92 * * *(0.01)$ & $0.91 * * *(0.01)$ & $0.91 * * *(0.01)$ & $0.91 * * *(0.01)$ \\
\hline & 1 & & & & Ref. & Ref. & Ref. \\
\hline & 2 & & & & $0.82 * *(0.06)$ & $0.81 * *(0.06)$ & $0.81 * *(0.06)$ \\
\hline & 3 & & & & $0.73 * * *(0.07)$ & $0.72 * * *(0.07)$ & $0.72 * * *(0.07)$ \\
\hline & 4 & & & & $0.78 * *(0.07)$ & $0.76^{* *}(0.07)$ & $0.76^{* *}(0.07)$ \\
\hline & 5 & & & & $0.79 *(0.09)$ & $0.78 *(0.09)$ & $0.78 *(0.09)$ \\
\hline & $6+$ & & & & $0.71 * *(0.08)$ & $0.69 * * *(0.08)$ & $0.70 * * *(0.08)$ \\
\hline \multirow[t]{2}{*}{ Urban } & No & Ref. & Ref. & Ref. & Ref. & Ref. & Ref. \\
\hline & Yes & $0.75 * *(0.07)$ & $0.76^{* *}(0.08)$ & $0.76^{* *}(0.08)$ & $0.93(0.06)$ & $0.95(0.06)$ & $0.95(0.06)$ \\
\hline \multirow{4}{*}{$\begin{array}{l}\text { Religious } \\
\quad \text { affiliation }\end{array}$} & Tidiane & Ref. & Ref. & Ref. & Ref. & Ref. & Ref. \\
\hline & Mouride & $0.99(0.10)$ & $0.94(0.10)$ & $0.94(0.10)$ & $0.86 *(0.06)$ & $0.84 *(0.06)$ & $0.84 * *(0.06)$ \\
\hline & Other Muslim & $0.94(0.12)$ & $0.94(0.13)$ & $0.93(0.13)$ & $0.98(0.08)$ & $1.03(0.09)$ & $1.03(0.09)$ \\
\hline & Other & $0.87(0.17)$ & $0.98(0.20)$ & $0.98(0.20)$ & $0.89(0.12)$ & $0.98(0.13)$ & $0.99(0.13)$ \\
\hline \multirow[t]{2}{*}{ Birth cohort } & Before 1965 & Ref. & Ref. & Ref. & Ref. & Ref. & Ref. \\
\hline & 1965 and after & $0.63 * * *(0.06)$ & $0.64 * * *(0.06)$ & $0.65^{* * *}(0.06)$ & $0.73^{* * *}(0.05)$ & $0.75^{* * *}(0.05)$ & $0.75^{* * *}(0.05)$ \\
\hline \multirow[t]{4}{*}{ Age } & $15-24$ & Ref. & Ref. & Ref. & Ref. & Ref. & Ref. \\
\hline & $25-34$ & $2.22 * * *(0.24)$ & $1.97 * * *(0.23)$ & $1.99 * * *(0.23)$ & $1.14(0.16)$ & $1.06(0.16)$ & $1.06(0.16)$ \\
\hline & $35-44$ & $2.80 * * *(0.46)$ & $2.39 * * *(0.40)$ & $2.24 * * *(0.38)$ & $1.11(0.16)$ & $1.03(0.16)$ & $1.01(0.16)$ \\
\hline & $45-60$ & $3.13 * *(1.29)$ & $3.16^{* *}(1.27)$ & $3.32 * *(1.40)$ & $0.63 * *(0.11)$ & $0.59 * *(0.11)$ & $0.58^{* *}(0.10)$ \\
\hline \multirow{4}{*}{$\begin{array}{l}\text { Residence of } \\
\text { partners, } \\
\text { combined }\end{array}$} & All SN & Ref. & Ref. & Ref. & Ref. & Ref. & Ref. \\
\hline & $\begin{array}{l}\text { Woman } \\
\text { (women) } \\
\text { SN, } \\
\text { man FIS }\end{array}$ & $0.66^{* *}(0.09)$ & $0.64^{* *}(0.09)$ & $0.85(0.14)$ & $0.52 * * *(0.04)$ & $0.50 * * *(0.04)$ & $0.55^{* * *}(0.05)$ \\
\hline & All FIS & $1.09(0.21)$ & $1.19(0.24)$ & $1.41+(0.29)$ & $0.59 * * *(0.05)$ & $0.60 * * *(0.05)$ & $0.61 * * *(0.05)$ \\
\hline & Other & $0.37 * * *(0.05)$ & $0.36^{* * *}(0.05)$ & $0.38 * * *(0.05)$ & $0.92(0.10)$ & $0.90(0.09)$ & $0.91(0.10)$ \\
\hline \multirow{2}{*}{$\begin{array}{l}\text { Polygamous } \\
\text { union }\end{array}$} & No & Ref. & Ref. & Ref. & Ref. & Ref. & Ref. \\
\hline & Yes & $0.69(0.17)$ & $0.68(0.17)$ & $0.67(0.17)$ & $2.25 * * *(0.17)$ & $2.27 * * *(0.17)$ & $2.25^{* * * *}(0.17)$ \\
\hline \multirow{4}{*}{$\begin{array}{l}\text { Education } \\
\text { partners, } \\
\text { combined }\end{array}$} & All primary & & Ref. & Ref. & & Ref. & Ref. \\
\hline & $\begin{array}{l}\text { Man secondary, } \\
\text { woman } \\
\text { (women) } \\
\text { primary }\end{array}$ & & $1.38 *(0.18)$ & $1.37 *(0.18)$ & & $0.90(0.06)$ & $0.90(0.06)$ \\
\hline & $\begin{array}{c}\text { Man primary, } \\
\text { at least } 1 \\
\text { woman } \\
\text { secondary }\end{array}$ & & $0.79(0.12)$ & $0.78(0.12)$ & & $0.90(0.09)$ & $0.90(0.09)$ \\
\hline & All secondary & & $0.89(0.11)$ & $0.90(0.11)$ & & $0.73 * * *(0.05)$ & $0.73^{* * *}(0.05)$ \\
\hline \multirow{2}{*}{$\begin{array}{l}\text { Economically } \\
\text { active }\end{array}$} & No & & Ref. & Ref. & & Ref. & Ref. \\
\hline & Yes & & $2.08 * * *(0.32)$ & $2.02 * * *(0.31)$ & & $1.57 * *(0.25)$ & $1.55^{* *}(0.25)$ \\
\hline \multirow{2}{*}{$\begin{array}{l}\text { Financial } \\
\text { situation } \\
\text { household }\end{array}$} & $\begin{array}{l}\text { Less than } \\
\text { sufficient }\end{array}$ & & Ref. & Ref. & & Ref. & Ref. \\
\hline & $\begin{array}{l}\text { Sufficient or } \\
\text { better }\end{array}$ & & $0.83+(0.08)$ & $0.81^{*}(0.08)$ & & $1.11+(0.07)$ & $1.10+(0.06)$ \\
\hline \multirow[t]{5}{*}{ Duration in FIS } & $\begin{array}{l}\text { 4+ years / } \\
\text { non-migrant }\end{array}$ & & Ref. & Ref. & & & Ref. \\
\hline & Arrival year & & & $0.74(0.25)$ & & & $0.51 *(0.14)$ \\
\hline & +1 year & & & $0.33 * *(0.14)$ & & & $0.90(0.21)$ \\
\hline & +2 years & & & $0.53+(0.18)$ & & & $0.57 *(0.16)$ \\
\hline & +3 years & & & $0.30 * *(0.13)$ & & & $0.98(0.23)$ \\
\hline$N$ (person-years) & & 3648 & 3648 & 3648 & 9212 & 9212 & 9212 \\
\hline
\end{tabular}

Data: MAFE-MESE Biographic Survey (2008/2011), unweighted

$+p<0.1, * p<0.05, * * p<0.01, * * * p<0.001$; exponentiated coefficients; standard errors in parentheses; missing values in the independent variables are included in the models but results are not displayed; $S N=$ Senegal, FIS=France, Italy or Spain 
The second hypothesis postulates that women and men who are spatially separated from their partner (or partners for polygamous men) due to outmigration experience a disruption in childbearing and, accordingly, have lower birth probabilities compared to non-migrants at origin (H2: Disruption and fertility timing). The geographic separation of couples-i.e. men in Europe and women staying in Senegal-during the preceding year results in significantly lower birth probabilities in the following year. This holds for first as well as higher-order births and in both the female and male models (W2, W5, M2, M5). Men's solo migration leads to significantly lower odds of having a child in a given year, thus confirming our second hypothesis.

The type of partnership is also related to the timing of births. The results indicate that birth transitions of women living with a co-wife in their current partnership are not significantly different from women in a monogamous union. Men in polygamous unions, however, have a more than the twofold probability of having a second or higher-order birth compared to monogamous men in a given year. An interaction effect combining the residence of the partners and the type of union (monogamous vs. polygamous) shows that this difference is largest in years when men are with their wife (wives) in Senegal and is smallest when men reside alone in Europe leaving their wife (wives) behind in Senegal (Fig. 1). This partially supports hypothesis 4 (H4: Disruption and polygamy), in which we expected that the depressive effect of migration on birth timing is strongest for polygamous migrant men compared to monogamous migrants.

The exponentiated coefficients for women and men also show that respondents residing with their partner(s) together in Europe have significantly lower odds of birth compared to women and men who stay with their partners at origin. This is true, however, only for second or higher-order births. On the contrary, for women who are in Europe with their husbands, significantly higher first-birth probabilities can be

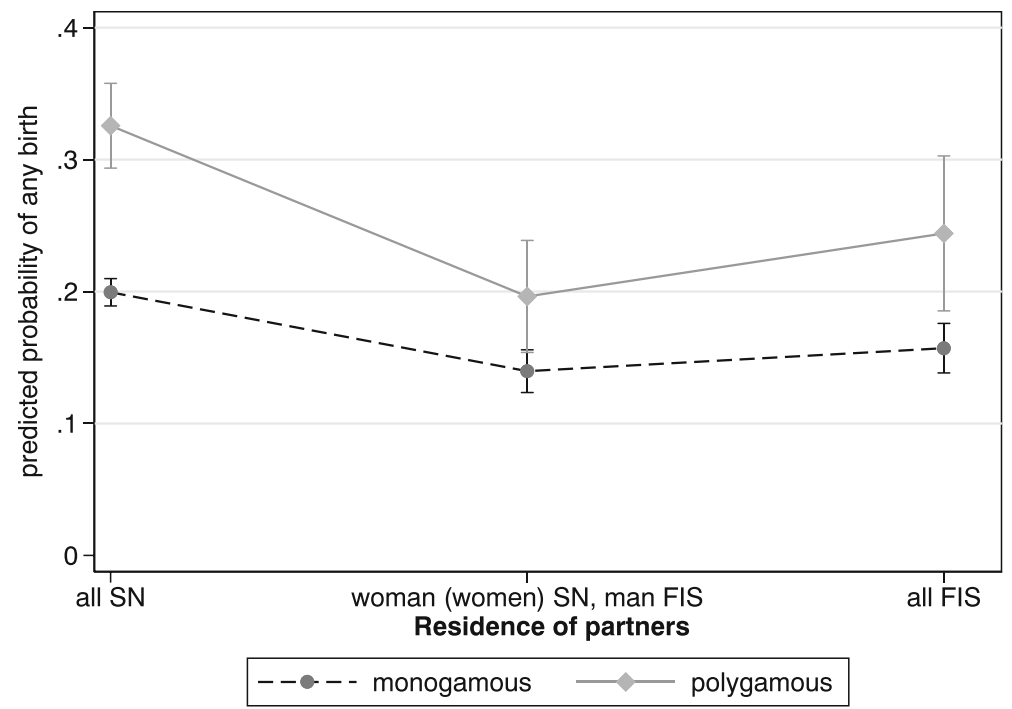

Fig. 1 Men: Fertility timing: Interaction of residence of partners and polygamous union. Predicted probabilities, 95\% confidence intervals. Data: MAFE-MESE Biographic Survey (2008/2011), unweighted dependent variable: transition to any birth; independent variables are the same as in model M6, Table 2, adding an interaction effect for residence of partners and polygamous union; SN=Senegal, FIS=France, Italy or Spain 
observed in the year of their arrival, compared to women who are together with their husbands at origin (W3). Similarly, higher-order birth risks - although low overall when both partners are together at destination-increase in the year when women arrive at destination to join their husband (W6). This leads us to confirm hypothesis 5 (H5: Interrelation of events and fertility timing), stating that Senegalese migrant women have high birth probabilities in the years immediately after arriving at their destination compared to non-migrant women. Independent of parity, migrant women experience a strong interrelation of the timing of their migration move and the ensuing fertility. Men, in contrast, have very low first and higher-order birth risks in the years of and following their arrival (M3, M6), as for them migration and arriving at destination basically means separation from their wife (wives).

The fertility-related control variables show significant results and point in the same direction for women and men. The more time passes after a birth (or since union formation for first births), the lower the probability of having a child. Moreover, the probabilities of a birth decrease with parity. Furthermore, the demographic covariates show that individuals with an urban background have lower birth probabilities. Members of the Mouride brotherhood have lower birth risks than those affiliated with the Tidiane brotherhood. With regard to the birth cohort, birth transitions slowed down for persons born in more recent years, indicating a slow decline in fertility rates in line with the fertility transition underway in many subSaharan African countries.

\section{Multivariate Results on Completed Fertility}

Table 3 (women) and Table 4 (men) present the incidence rate ratios for completed fertility at age 40. Regarding the positive socioeconomic selectivity of migrants, hypothesis 1 postulated that fertility differentials between migrant and non-migrant men and women should diminish when controlling for their socioeconomic characteristics (H1: Selection and fertility timing and completed fertility). However, there is no support for this in the data. For both women and men, the effect of migration experience on the number of children remains essentially the same after adding the covariate for the partners' combined educational attainment. This is in line with the results on fertility timing presented in the previous section, where we also included other dimensions of socioeconomic status (labour force status and financial situation) to capture migrant selectivity.

Regarding fertility disruption, we expected that women and men who are either themselves a migrant and/or have a migrant partner show lower completed fertility compared to non-migrant men and women (H3: Disruption and completed fertility). The results for women clearly show that being a migrant is associated with a lower number of births compared to their non-migrant counterparts, and thus, hypothesis 3 could be confirmed. Non-migrant women with a migrant partner have also fewer children than those with a non-migrant husband, but this becomes insignificant ( $p<$ 0.11) after adding the measure for education (model W8, Table 3). Changing the reference category in the female models, the results show that migrant women with a non-migrant partner have a significantly lower completed fertility $(p<0.05)$ compared to migrant women with a migrant partner, indicating that these female solo migrants are highly selective with low fertility levels. For men, however, there is no significant 
Table 3 Women: Completed fertility: Poisson regression models predicting total number of births at age 40 (incidence rate ratio)

\begin{tabular}{|c|c|c|c|c|c|}
\hline & & complete & (W7) & complet & (W8) \\
\hline \multirow[t]{2}{*}{ Urban } & No & Ref. & & Ref. & \\
\hline & Yes & 0.93 & $(0.05)$ & 1.00 & $(0.05)$ \\
\hline \multirow[t]{4}{*}{ Religious affiliation } & Tidiane & Ref. & & Ref. & \\
\hline & Mouride & 0.94 & $(0.06)$ & 0.93 & $(0.05)$ \\
\hline & Other Muslim & 0.92 & $(0.09)$ & 0.98 & $(0.08)$ \\
\hline & Other & 0.90 & $(0.12)$ & 0.91 & $(0.11)$ \\
\hline \multirow[t]{2}{*}{ Birth cohort } & Before 1965 & Ref. & & Ref. & \\
\hline & $1965-74$ & $0.87^{*}$ & $(0.05)$ & $0.88^{*}$ & $(0.05)$ \\
\hline \multirow[t]{2}{*}{ Co-wife in union } & No & Ref. & & Ref. & \\
\hline & Yes & 1.08 & $(0.06)$ & 1.05 & $(0.05)$ \\
\hline \multirow{4}{*}{$\begin{array}{l}\text { Migration experience } \\
\text { partners, combined }\end{array}$} & Both non-migrants & Ref. & & Ref. & \\
\hline & Woman ever FIS, man non-migrant & $0.60^{* * * *}$ & $(0.07)$ & $0.63 * * *$ & $(0.07)$ \\
\hline & Woman non-migrant, man ever FIS & $0.86+$ & $(0.08)$ & 0.87 & $(0.07)$ \\
\hline & Both ever FIS & $0.73 * * *$ & $(0.05)$ & $0.75 * * *$ & $(0.05)$ \\
\hline \multirow{4}{*}{$\begin{array}{l}\text { Education partners, } \\
\text { combined }\end{array}$} & Both primary & & & Ref. & \\
\hline & Woman secondary, man primary & & & $0.65 * * *$ & $(0.06)$ \\
\hline & Woman primary, man secondary & & & $0.89+$ & $(0.06)$ \\
\hline & Both secondary & & & $0.73 * * *$ & $(0.05)$ \\
\hline \multicolumn{2}{|l|}{$N$} & 426 & & 426 & \\
\hline
\end{tabular}

Data: MAFE-MESE Biographic Survey (2008/2011), unweighted

$+p<0.1, * p<0.05, * * p<0.01, * * * p<0.001$; exponentiated coefficients; standard errors in parentheses; missing values in the independent variables are included in the models but results are not displayed; FIS=France, Italy, Spain

difference in the number of children between being a migrant with a non-migrant wife (wives) or with a migrant wife (wives).

Finally, regarding hypothesis 4 (H4: Disruption and polygamy), we anticipated that for polygamous men the depressing effect of migration on completed fertility should be stronger than for monogamous men. Table 4 shows that men who have several simultaneous unions have significantly higher completed fertility. The graphic presentation of the interaction effect of migration experience at age 40 and the type of union (Fig. 2) displays that this effect is mainly driven by the polygamous: while for monogamous men, there is no significant negative effect of being a migrant on the number of children born, for polygamous men, this negative effect is large and highly significant. Thus, H4 could be confirmed. As men often become polygamous at higher ages, and here we only account for polygamy and fertility up to the age of 40, the effect of having two or more simultaneous unions on the completed fertility of migrants might even be underestimated. For women, the incidence rate ratios indicate that living with one or several co-wives does not affect the number of children they have up to age 40, which is not in line with previous research that showed that women in polygamous unions compared to women in monogamous unions had lower fertility (Lardoux and Van de Walle 2003). 
Table 4 Men: Completed fertility: Poisson regression models predicting total number of births at age 40 (incidence rate ratios)

\begin{tabular}{|c|c|c|c|c|c|}
\hline & & complete & & complete & \\
\hline Urban & No & Ref. & & Ref. & \\
\hline & Yes & 0.93 & $(0.06)$ & 0.93 & $(0.06)$ \\
\hline Religious affiliation & Tidiane & Ref. & & Ref. & \\
\hline & Mouride & 0.91 & $(0.06)$ & 0.90 & $(0.06)$ \\
\hline & Other Muslim & 0.89 & $(0.09)$ & 0.89 & $(0.09)$ \\
\hline & Other & 0.83 & $(0.11)$ & 0.83 & $(0.11)$ \\
\hline Birth cohort & Before 1965 & Ref. & & Ref. & \\
\hline & $1965-74$ & $0.81 * *$ & $(0.06)$ & $0.80^{* *}$ & $(0.05)$ \\
\hline Polygamous union & No & Ref. & & Ref. & \\
\hline & Yes & $1.84 * * *$ & $(0.13)$ & $1.83 * * *$ & $(0.13)$ \\
\hline Migration experience & All non-migrants & Ref. & & Ref. & \\
\hline partners, combined & $\begin{array}{l}\text { Man ever FIS, woman } \\
\text { (women) non-migrant }\end{array}$ & $0.76^{* * *}$ & $(0.05)$ & $0.76^{* * * *}$ & $(0.05)$ \\
\hline & $\begin{array}{l}\text { Man ever FIS, at least } 1 \\
\text { woman ever FIS }\end{array}$ & $0.73 * * *$ & $(0.07)$ & $0.75^{* *}$ & $(0.07)$ \\
\hline Education partners, & All primary & & & Ref. & \\
\hline combined & $\begin{array}{l}\text { Man secondary, woman } \\
\text { (women) primary }\end{array}$ & & & 1.10 & $(0.09)$ \\
\hline & $\begin{array}{l}\text { Man primary, at least } 1 \\
\text { woman secondary }\end{array}$ & & & 0.98 & $(0.10)$ \\
\hline & $\begin{array}{l}\text { Man secondary, at least } 1 \\
\text { woman secondary }\end{array}$ & & & 0.94 & $(0.08)$ \\
\hline$N$ & & 450 & & 450 & \\
\hline
\end{tabular}

Data: MAFE-MESE Biographic Survey (2008/2011), unweighted

$+p<0.1, * p<0.05, * * p<0.01, * * * p<0.001$; exponentiated coefficients; standard errors in parentheses; missing values in the independent variables are included in the models but results are not displayed; FIS=France, Italy, Spain

Regarding the demographic control variables, the results show that the number of children decreases for the younger birth cohort, both for women and men, and that religious affiliation and urban background have no significant effect.

\section{Conclusion}

The aim of this article was to compare the fertility behaviour of migrants and those who stay at origin by taking a 'country-of-origin' or dissimilation perspective and considering the polygamous setting in Senegal. In order to disentangle selection effects determining the fertility behaviour of migrants, other mechanisms explaining migrant fertility were also examined (disruption, interrelation of events), as several may be at work either simultaneously or sequentially. Overall, we found evidence for both differences in fertility timing and completed fertility between migrants and stayers at origin. A strong disruptive effect of migration on childbearing could be observed, clearly related to the 


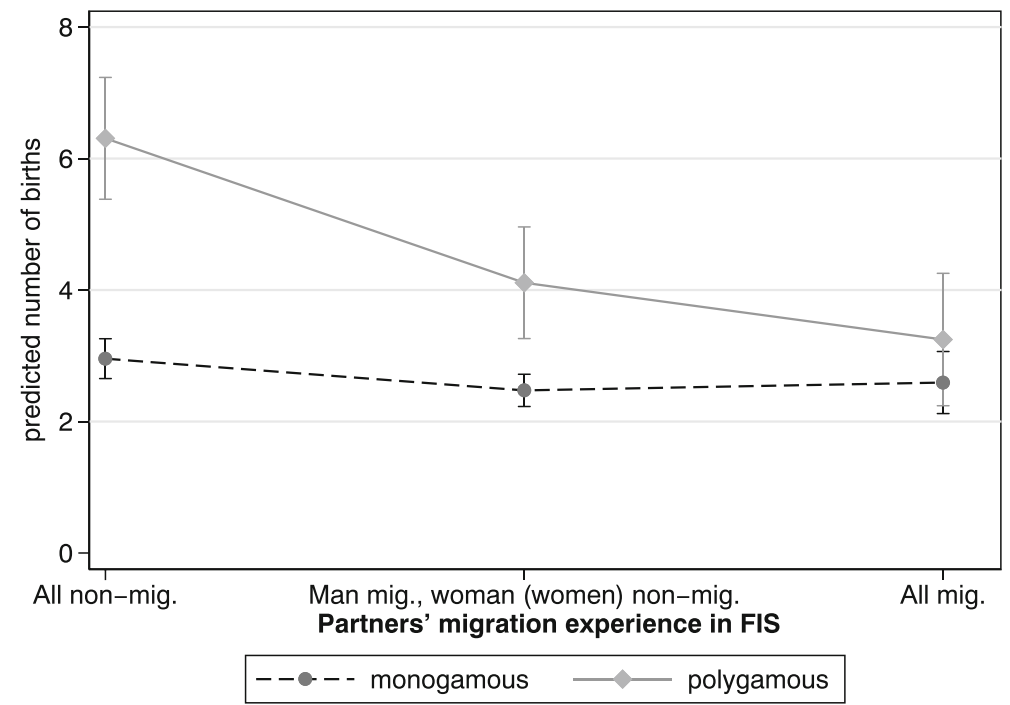

Fig. 2 Men: Completed fertility: Interaction of migration experience and polygamous union. Predicted number of births, 95\% confidence intervals. Data: MAFE-MESE Biographic Survey, unweighted. dependent variable: number of births; independent variables are the same as in model M8, Table 4, adding an interaction effect for migration experience of partners and polygamous union; FIS=France, Italy or Spain

geographic separation of couples due to the out-migration of the man. Women were less likely to experience a birth in a given year when their partner was in Europe in the prior year. This is true for first births as well as higher-order births. Combining data on the migration status of the respondent and their partner(s) analytically enabled linking disrupted fertility to the separation of partners, which could not have been done without the information on partner's migratory movements. Concerning completed fertility, migrant women and men have significantly fewer children throughout their reproductive life course compared to their non-migrant counterparts. Part of this difference can surely be explained by the prolonged separation of partners, making fertility recovery difficult or impossible. Yet, our results suggest that the major reason why Senegalese migrant men have fewer children than their non-migrant counterparts is related to polygamy, as polygamous migrants apparently do not recover their fertility, and their completed fertility by the age of 40 remains lower than that of non-migrant polygamous men. On the contrary, for female fertility outcomes, our data do not show any effect of living in a polygamous union with another wife in this context.

Against our expectations, selectivity on observable characteristics such as educational attainment and economic performance and resources could not explain the fertility differences between migrants and stayers. It can be assumed, however, that, at least part of the differences in fertility between migrants and non-migrants are the result of selectivity on unobservable characteristics. Some authors argue that migrants have intrinsic preferences or personality traits that are difficult or impossible to measure that shape their fertility outcomes, such as social mobility aspirations (Milewski 2007), openness to innovation (Lindstrom and Giorguli-Saucedo 2002), high aspirations for children and family proneness (Baykara-Krumme and Milewski 2017; Kulu and González-Ferrer 2014; Lindstrom and Giorguli-Saucedo 2007). Unfortunately, the MAFE survey does not provide this information. Another partial explanation for the 
lower fertility of migrants might be adaptation or convergence processes towards lower fertility levels and higher costs of childbearing and childrearing in European destination countries. Low second and higher-order birth probabilities of migrant women and men residing together at the destination might be an indication for this.

Another issue covered to a lesser extent in the standard explanations for migrants' fertility behaviour and previous research, and providing another perspective to the results presented here, is that having children under specific circumstances may also entail benefits or advantages, in particular for women, going beyond the argumentation of childbearing being the result of differential costs and opportunities. For instance, in many sub-Saharan African societies, young women see their children as 'the key to security in her husband's home and a bulwark against competition from present or future co-wives' (Bledsoe et al. 2007, p. 388). Giving birth to many children may be seen as a strategy of a woman to strengthen her position within the extended (polygamous) family. For migrant women, in contrast, having a fast transition to a (first) child shortly upon arrival in the destination country has been interpreted as a legal strategy to get the citizenship of the respective country for that child and sometimes the parents themselves (Lindstrom and Giorguli-Saucedo 2007; Milewski 2007). Although this does not apply to the countries under study, other advantages may emerge in European destination countries, such as social security and health care benefits, or the children's right to education (Bledsoe et al. 2007; Bledsoe and Sow 2008).

While the current study contributes to the existing research on migrant fertility, several limitations should be mentioned. First, the formulated hypotheses and the analytical approach are based on the assumption that migration shapes fertility behaviour; however, fertility may also influence migration decisions, as has been shown in several studies (Lindstrom and Giorguli-Saucedo 2007; Ribe and Schultz 1980). Births are not only postponed as a consequence of couple separation, but migration may also be initiated or delayed as a result of a birth. Second, another issue that could not be addressed in this study is that fertility differences between migrants and stayers may operate through differential selection processes into partnerships, as has been found for Senegal (Marchetta and Sahn 2015). For instance, women marrying a migrant, and especially marriage migrants, probably are selected on socioeconomic factors, as well as on their aspirations for marrying a migrant and eventually following him to Europe and having a child there. Moreover, both men and women entering a polygamous union are selected on socioeconomic characteristics, which ultimately also determine their migration behaviour as well as their fertility desires and outcomes. Third, the models do not account for the specific destination country (France, Italy, Spain), although fertility levels, socioeconomic conditions and the social and economic integration of migrants may vary across destinations and Senegalese migration to France has a much more established colonial and migratory history than migration to the other two countries. Investigating the effect that different receiving contexts may have on the fertility behaviour of the same migrant group is a relevant issue for further research, which goes beyond the country-of-origin-perspective of this study. Notwithstanding these limitations, the current research provides some new perspectives as well as innovative theoretical and empirical insights to existing theories on the family formation of migrant populations and especially for migration flows from sub-Saharan Africa and other polygamous settings. 


\section{Appendix}

Table 5 Women: Descriptive statistics of variables. Percentages of person-years at risk and number of birth events by time-varying migrant status of respondent

\begin{tabular}{|c|c|c|c|c|c|c|c|}
\hline & & \multicolumn{6}{|c|}{ Respondent's residence during person-year (t-1) in... } \\
\hline & & \multicolumn{2}{|l|}{$\ldots \mathrm{SN}$} & \multicolumn{2}{|l|}{$\ldots$ FIS } & \multicolumn{2}{|l|}{...Other } \\
\hline & & $\begin{array}{l}\text { Exposure } \\
\text { (person- } \\
\text { years, \%) }\end{array}$ & $\begin{array}{l}\text { Number } \\
\text { of births }\end{array}$ & $\begin{array}{l}\text { Exposure } \\
\text { (person- } \\
\text { years, \%) }\end{array}$ & $\begin{array}{l}\text { Number } \\
\text { of births }\end{array}$ & $\begin{array}{l}\text { Exposure } \\
\text { (person- } \\
\text { years, \%) }\end{array}$ & $\begin{array}{l}\text { Number } \\
\text { of births }\end{array}$ \\
\hline \multirow[t]{7}{*}{ Parity (tv) } & 0 & 19.8 & 640 & 19.8 & 122 & 26.4 & 16 \\
\hline & 1 & 13.9 & 522 & 22.0 & 114 & 24.5 & 19 \\
\hline & 2 & 13.6 & 398 & 19.7 & 81 & 23.7 & 15 \\
\hline & 3 & 14.0 & 309 & 15.2 & 53 & 11.2 & 9 \\
\hline & 4 & 10.9 & 196 & 9.6 & 35 & 5.1 & 7 \\
\hline & 5 & 9.0 & 155 & 3.9 & 23 & 3.8 & 5 \\
\hline & $6+$ & 18.9 & 287 & 9.9 & 24 & 5.3 & 7 \\
\hline \multirow[t]{3}{*}{ Urban (tc) } & No & 67.2 & 1575 & 50.7 & 198 & 80.2 & 52 \\
\hline & Yes & 27.0 & 822 & 43.3 & 211 & 13.7 & 26 \\
\hline & missing & 5.9 & 110 & 6.0 & 43 & 6.1 & 0 \\
\hline \multirow{5}{*}{$\begin{array}{l}\text { Religious } \\
\text { affiliation } \\
\text { (tc) }\end{array}$} & Tidiane & 56.5 & 1332 & 35.7 & 182 & 61.9 & 49 \\
\hline & Mouride & 31.6 & 778 & 22.3 & 127 & 29.0 & 15 \\
\hline & Other Muslim & 7.9 & 261 & 21.3 & 100 & 8.8 & 8 \\
\hline & Other & 3.2 & 104 & 8.8 & 27 & 0.1 & 4 \\
\hline & missing & 0.8 & 32 & 12.0 & 16 & 0.2 & 2 \\
\hline \multirow{2}{*}{$\begin{array}{l}\text { Birth cohort } \\
\quad \text { (tc) }\end{array}$} & Before 1965 & 60.0 & 1315 & 43.8 & 111 & 55.3 & 47 \\
\hline & 1965 and after & 40.0 & 1192 & 56.2 & 341 & 44.7 & 31 \\
\hline \multirow[t]{3}{*}{ Age (tv) } & $15-24$ & 31.1 & 1021 & 10.5 & 99 & 36.3 & 30 \\
\hline & $25-34$ & 41.7 & 1157 & 47.9 & 239 & 49.4 & 40 \\
\hline & $35-45$ & 27.3 & 329 & 41.7 & 114 & 14.3 & 8 \\
\hline \multirow{3}{*}{$\begin{array}{l}\text { Co-wife in } \\
\text { union (tv) }\end{array}$} & No & 54.6 & 1509 & 85.4 & 360 & 77.2 & 45 \\
\hline & Yes & 44.6 & 977 & 13.9 & 87 & 20.7 & 31 \\
\hline & missing & 0.8 & 21 & 0.8 & 5 & 2.1 & 2 \\
\hline \multirow{3}{*}{$\begin{array}{l}\text { Residence of } \\
\text { partner (tv, } \\
\mathrm{t}-1)\end{array}$} & $\mathrm{SN}$ & 78.6 & 1900 & 5.7 & 29 & 33.4 & 9 \\
\hline & FIS & 5.6 & 309 & 85.4 & 417 & 9.9 & 10 \\
\hline & Elsewhere & 15.9 & 298 & 8.9 & 6 & 56.7 & 59 \\
\hline \multirow{5}{*}{$\begin{array}{l}\text { Education } \\
\text { partners, } \\
\text { combined } \\
\text { (tc) }\end{array}$} & Both primary & 57.3 & 1249 & 23.6 & 185 & 28.2 & 38 \\
\hline & $\begin{array}{l}\text { Woman secondary, } \\
\text { man primary prim. }\end{array}$ & 5.8 & 171 & 17.1 & 80 & 8.5 & 11 \\
\hline & $\begin{array}{l}\text { Woman primary, } \\
\text { man secondary }\end{array}$ & 21.9 & 530 & 13.8 & 54 & 28.7 & 12 \\
\hline & Both secondary & 11.4 & 451 & 41.7 & 122 & 29.8 & 15 \\
\hline & missing & 3.7 & 106 & 3.9 & 11 & 4.9 & 2 \\
\hline
\end{tabular}


Table 5 (continued)

\begin{tabular}{|c|c|c|c|c|c|c|c|}
\hline & & \multicolumn{6}{|c|}{ Respondent's residence during person-year $(t-1)$ in... } \\
\hline & & \multicolumn{2}{|l|}{$\ldots \mathrm{SN}$} & \multicolumn{2}{|l|}{...FIS } & \multicolumn{2}{|l|}{...Other } \\
\hline & & $\begin{array}{l}\text { Exposure } \\
\text { (person- } \\
\text { years, \%) }\end{array}$ & $\begin{array}{l}\text { Number } \\
\text { of births }\end{array}$ & $\begin{array}{l}\text { Exposure } \\
\text { (person- } \\
\text { years, \%) }\end{array}$ & $\begin{array}{l}\text { Number } \\
\text { of births }\end{array}$ & $\begin{array}{l}\text { Exposure } \\
\text { (person- } \\
\text { years, \%) }\end{array}$ & $\begin{array}{l}\text { Number } \\
\text { of births }\end{array}$ \\
\hline \multirow{2}{*}{$\begin{array}{l}\text { Economically } \\
\text { active (tv, } \\
\mathrm{t}-1)\end{array}$} & No & 64.7 & 1634 & 43.3 & 245 & 53.3 & 47 \\
\hline & Yes & 35.3 & 873 & 56.7 & 207 & 46.7 & 31 \\
\hline \multirow{3}{*}{$\begin{array}{l}\text { Financial } \\
\quad \text { situation } \\
\text { household } \\
\text { (tv, t-1) }\end{array}$} & Less than sufficient & 42.0 & 831 & 26.1 & 131 & 18.0 & 20 \\
\hline & Sufficient or better & 57.7 & 1672 & 73.8 & 321 & 82.0 & 58 \\
\hline & missing & 0.3 & 4 & 0.1 & 0 & 0.0 & 0 \\
\hline \multirow{6}{*}{$\begin{array}{l}\text { Duration in } \\
\text { FIS } \\
(\mathrm{tv}, \mathrm{t}-1)\end{array}$} & $\begin{array}{l}\text { 4+ years / } \\
\text { non-migrant }\end{array}$ & & & 64.9 & 220 & & \\
\hline & Arrival year & & & 9.6 & 93 & & \\
\hline & +1 year & & & 9.6 & 55 & & \\
\hline & +2 years & & & 8.3 & 47 & & \\
\hline & +3 years & & & 7.7 & 37 & & \\
\hline & Total & 94.4 & 2507 & 4.1 & 452 & 1.5 & 78 \\
\hline
\end{tabular}

Data: MAFE-MESE Biographic Survey (2008/2011), weighted percentages.

percentages may not total $100 \%$ due to rounding; tv=time-varying, tc=time-constant; SN=Senegal, FIS=France, Italy, Spain 
Table 6 Men: Descriptive statistics of variables. Percentages of person-years at risk and number of birth events by time-varying migrant status of respondent

\begin{tabular}{|c|c|c|c|c|c|c|c|}
\hline & & \multicolumn{6}{|c|}{ Respondent's residence during person-year (t-1) in... } \\
\hline & & \multicolumn{2}{|l|}{$\ldots \mathrm{SN}$} & \multicolumn{2}{|l|}{...FIS } & \multicolumn{2}{|l|}{...Other } \\
\hline & & $\begin{array}{l}\text { Exposure } \\
\text { (person- } \\
\text { years, } \% \text { ) }\end{array}$ & $\begin{array}{l}\text { Number } \\
\text { of births }\end{array}$ & $\begin{array}{l}\text { Exposure } \\
\text { (person- } \\
\text { years, \%) }\end{array}$ & $\begin{array}{l}\text { Number } \\
\text { of births }\end{array}$ & $\begin{array}{l}\text { Exposure } \\
\text { (person- } \\
\text { years, \%) }\end{array}$ & $\begin{array}{l}\text { Number } \\
\text { of births }\end{array}$ \\
\hline \multirow[t]{7}{*}{ Parity (tv) } & 0 & 25.7 & 417 & 23.7 & 142 & 22.1 & 27 \\
\hline & 1 & 13.2 & 340 & 21.4 & 128 & 15.0 & 18 \\
\hline & 2 & 12.9 & 242 & 20.0 & 112 & 9.5 & 13 \\
\hline & 3 & 11.8 & 169 & 14.0 & 75 & 4.9 & 13 \\
\hline & 4 & 5.6 & 126 & 8.2 & 57 & 15.9 & 15 \\
\hline & 5 & 6.6 & 116 & 5.2 & 36 & 8.2 & 10 \\
\hline & $6+$ & 24.2 & 336 & 7.4 & 60 & 24.4 & 25 \\
\hline \multirow[t]{3}{*}{ Urban (tc) } & No & 66.0 & 1160 & 52.8 & 353 & 68.6 & 90 \\
\hline & Yes & 29.5 & 531 & 45.2 & 241 & 30.4 & 28 \\
\hline & missing & 4.5 & 55 & 2.0 & 16 & 1.1 & 3 \\
\hline \multirow{5}{*}{$\begin{array}{l}\text { Religious } \\
\text { affiliation (tc) }\end{array}$} & Tidiane & 40.3 & 716 & 29.7 & 218 & 41.2 & 48 \\
\hline & Mouride & 36.5 & 602 & 40.0 & 240 & 43.5 & 47 \\
\hline & Other Muslim & 16.6 & 318 & 15.5 & 95 & 9.0 & 14 \\
\hline & Other & 6.3 & 94 & 6.6 & 26 & 2.1 & 11 \\
\hline & missing & 0.4 & 16 & 8.2 & 31 & 4.2 & 1 \\
\hline \multirow[t]{2}{*}{ Birth cohort (tc) } & Before 1965 & 62.0 & 1190 & 63.4 & 381 & 80.0 & 97 \\
\hline & 1965 and after & 38.1 & 556 & 36.6 & 229 & 20.0 & 24 \\
\hline \multirow[t]{4}{*}{ Age (tv) } & $15-24$ & 11.9 & 168 & 2.6 & 19 & 8.7 & 10 \\
\hline & $25-34$ & 39.7 & 796 & 35.0 & 206 & 31.4 & 47 \\
\hline & $35-44$ & 27.9 & 556 & 40.2 & 297 & 42.2 & 44 \\
\hline & $45-60$ & 20.6 & 226 & 22.2 & 88 & 17.7 & 20 \\
\hline \multirow{2}{*}{$\begin{array}{l}\text { Polygamous } \\
\text { union (tv) }\end{array}$} & No & 83.5 & 1373 & 83.7 & 469 & 80.4 & 93 \\
\hline & Yes & 16.5 & 373 & 16.3 & 141 & 19.6 & 28 \\
\hline \multirow{4}{*}{$\begin{array}{l}\text { Residence of } \\
\text { partner(s) (tv, } \\
\text { t-1) }\end{array}$} & $\mathrm{SN}$ & 90.2 & 1600 & 57.3 & 356 & 69.1 & 79 \\
\hline & FIS & 0.9 & 18 & 36.7 & 225 & 1.7 & 2 \\
\hline & Elsewhere & 1.4 & 47 & 1.4 & 11 & 23.0 & 36 \\
\hline & missing & 7.6 & 81 & 4.6 & 18 & 6.3 & 4 \\
\hline \multirow{6}{*}{$\begin{array}{l}\text { Education } \\
\text { partners, } \\
\text { combined } \\
\text { (tc) }\end{array}$} & All primary & 52.9 & 888 & 37.7 & 259 & 48.3 & 71 \\
\hline & $\begin{array}{l}\text { Man } \\
\text { secondary, } \\
\text { woman } \\
\text { primary }\end{array}$ & 19.3 & 356 & 18.4 & 119 & 16.5 & 18 \\
\hline & $\begin{array}{l}\text { Man primary, } \\
\text { woman } \\
\text { secondary }\end{array}$ & 7.2 & 113 & 7.8 & 73 & 10.0 & 6 \\
\hline & All secondary & 19.6 & 373 & 35.1 & 152 & 25.2 & 26 \\
\hline & missing & 1.1 & 16 & 1.0 & 7 & & \\
\hline & No & 13.5 & 123 & 6.3 & 20 & 8.1 & 5 \\
\hline
\end{tabular}


Table 6 (continued)

\begin{tabular}{|c|c|c|c|c|c|c|c|}
\hline & & \multicolumn{6}{|c|}{ Respondent's residence during person-year (t-1) in... } \\
\hline & & \multicolumn{2}{|l|}{$\ldots \mathrm{SN}$} & \multicolumn{2}{|l|}{...FIS } & \multicolumn{2}{|l|}{...Other } \\
\hline & & $\begin{array}{l}\text { Exposure } \\
\text { (person- } \\
\text { years, \%) }\end{array}$ & $\begin{array}{l}\text { Number } \\
\text { of births }\end{array}$ & $\begin{array}{l}\text { Exposure } \\
\text { (person- } \\
\text { years, \%) }\end{array}$ & $\begin{array}{l}\text { Number } \\
\text { of births }\end{array}$ & $\begin{array}{l}\text { Exposure } \\
\text { (person- } \\
\text { years, \%) }\end{array}$ & $\begin{array}{l}\text { Number } \\
\text { of births }\end{array}$ \\
\hline $\begin{array}{l}\text { Economically } \\
\text { active } \\
(\mathrm{tv}, \mathrm{t}-1)\end{array}$ & $\begin{array}{l}\text { Yes } \\
\text { missing }\end{array}$ & 86.5 & $\begin{array}{l}1623 \\
0\end{array}$ & 93.7 & 590 & 1.9 & 116 \\
\hline \multirow{3}{*}{$\begin{array}{l}\text { Financial } \\
\text { situation } \\
\text { household } \\
(\mathrm{tv}, \mathrm{t}-1)\end{array}$} & $\begin{array}{l}\text { Less than } \\
\text { sufficient }\end{array}$ & 33.3 & 626 & 26.5 & 195 & 14.8 & 26 \\
\hline & $\begin{array}{l}\text { Sufficient or } \\
\text { better }\end{array}$ & 63.2 & 1104 & 73.2 & 413 & 84.6 & 95 \\
\hline & missing & 3.5 & 16 & 0.4 & 2 & 0.6 & 0 \\
\hline \multirow[t]{6}{*}{$\begin{array}{l}\text { Duration in FIS } \\
\quad(\mathrm{tv}, \mathrm{t}-1)\end{array}$} & $\begin{array}{l}\text { 4+ years / } \\
\text { non-migrant }\end{array}$ & & & 78.2 & 496 & & \\
\hline & Arrival year & & & 5.5 & 29 & & \\
\hline & +1 year & & & 5.5 & 32 & & \\
\hline & +2 years & & & 5.5 & 25 & & \\
\hline & +3 years & & & 5.4 & 28 & & \\
\hline & Total & 81.2 & 1746 & 15.9 & 610 & 2.9 & 121 \\
\hline
\end{tabular}

Data: MAFE-MESE Biographic Survey (2008/2011), weighted percentages.

percentages may not total $100 \%$ due to rounding; tv=time-varying, tc=time-constant; SN=Senegal, FIS=France, Italy, Spain

Acknowledgements The research leading to these results has received funding from the European Community's Seventh Framework Programme (grant 217206) and the Spanish Ministry of Science and Technology (grant CSO2009-12816). We are very grateful for the comments and support provided by Alícia Adserà and Nadja Milewski and for the useful suggestions of two anonymous reviewers.

Funding Open Access funding enabled and organized by Projekt DEAL.

\section{Declarations}

Conflict of Interest The authors declare that they have no conflict of interest.

Open Access This article is licensed under a Creative Commons Attribution 4.0 International License, which permits use, sharing, adaptation, distribution and reproduction in any medium or format, as long as you give appropriate credit to the original author(s) and the source, provide a link to the Creative Commons licence, and indicate if changes were made. The images or other third party material in this article are included in the article's Creative Commons licence, unless indicated otherwise in a credit line to the material. If material is not included in the article's Creative Commons licence and your intended use is not permitted by statutory regulation or exceeds the permitted use, you will need to obtain permission directly from the copyright holder. To view a copy of this licence, visit http://creativecommons.org/licenses/by/4.0/. 


\section{References}

Adserà, A., \& Ferrer, A. M. (2014). Immigrants and demography: Marriage, divorce, and fertility. IZA Working Paper. (No. 7982)

Agadjanian, V., Yabiku, S. T., \& Cau, B. (2011). Men's migration and women's fertility in rural Mozambique. Demography, 48(3), 1029-1048. https://doi.org/10.1007/s13524-011-0039-y.

Andersson, G. (2004). Childbearing after migration: Fertility patterns of foreign-born women in Sweden. International Migration Review, 38(2), 747-775. https://doi.org/10.1111/j.1747-7379.2004.tb00216.x.

ANSD-Agence Nationale de la Statistique et de la Démographie (2014). Rapport Definitif, RGPHAE 2013. Dakar. Retrieved January 7, 2021, from https://www.ansd.sn/ressources/rapports/Rapport-definitifRGPHAE2013.pdf. Accessed 31 Jan 2021.

Antoine, P. (2006). The complexities of nuptiality: From early female union to male polygamy in Africa. In G. Caselli, J. Vallin, \& G. Wunsch (Eds.), Demography: Analysis and synthesis. A treatise in population studies (Vol. 355-371). Elsevier.

Antoine, P., \& Nanitelamio, J. (1996). Can polygyny be avoided in Dakar? In K. Sheldon (Ed.), Courtyards, markets, city streets: Urban women in Africa (pp. 129-152). Westview Press.

Baizán, P., Beauchemin, C., \& González-Ferrer, A. (2014). An origin and destination perspective on family reunification: The case of Senegalese couples. European Journal of Population, 30(1), 65-87. https://doi. org/10.1007/s10680-013-9305-6.

Barou, J. (2001). La famille à distance. Nouvelles stratégies familiales chez les immigrés d'Afrique sahélienne. In Revue Hommes et migrations. (1232), 16-25. https://doi.org/10.3406/homig.2001.3715.

Bass, L., \& Sow, F. (2006). Senegalese families: The confluence of ethnicity, history, and social change. In Y. Oheneba-Sakyi \& B. K. Takyi (Eds.), African families at the turn of the 21st century (pp. 83-102). Praeger Publisher.

Baykara-Krumme, H., \& Milewski, N. (2017). Fertility patterns among Turkish women in Turkey and abroad: The effects of international mobility, migrant generation, and family background. European Journal of Population, 33(3), 409-436. https://doi.org/10.1007/s10680-017-9413-9.

Beauchemin, C., \& González-Ferrer, A. (2011). Sampling international migrants with origin-based snowballing method: New evidence on biases and limitations. Demographic Research, 25(3), 103-134. https://doi.org/10.4054/DemRes.2011.25.3.

Beauchemin, C., Caarls, K., \& Mazzucato, V. (2013). Senegalese migrants between here and there: An overview of family patterns. MAFE Working Paper (No. 33). INED. Retrieved January 31, 2021, from https://mafeproject.site.ined.fr/en/publications/working_papers/. Accessed 31 Jan 2021.

Beauchemin, C., Sakho, P., Schoumaker, B., \& Flahaux, M.-L. (2014). New patterns of migration between Senegal and Europe. MAFE Working Paper (No. 21). INED. Retrieved January 31, 2021, from https:// mafeproject.site.ined.fr/en/publications/working_papers/. Accessed 31 Jan 2021.

Beauchemin, C., Nappa, J., Schoumaker, B., Baizán, P., González-Ferrer, A., Caarls, K., \& Mazzucato, V. (2015). Reunifying versus living apart together across borders: A comparative analysis of sub-Saharan migration to Europe. International Migration Review, 49(1), 173-199. https://doi.org/10.1111/imre. 12155.

Bledsoe, C. H. (2004). Reproduction at the margins: Migration and legitimacy in the New Europe. Demographic Research, Special Collection 3 (Article 4), 87-116. https://doi.org/10.4054/DemRes.2004.S3.4.

Bledsoe, C. H., \& Sow, P. (2008). Family reunification ideals and the practice of transnational reproductive life among Africans in Europe. MPIDR Working Papers (2008-01). https://doi.org/10.4054/MPIDR-WP-2008-001.

Bledsoe, C. H., Houle, R., \& Sow, P. (2007). High fertility Gambians in low fertility Spain. Demographic Research, 16, 375-412. https://doi.org/10.4054/DemRes.2007.16.12.

Bongaarts, J. (2003). Completing the fertility transition in the developing world: The role of educational differences and fertility preferences. Population Studies, 57(3), 321-335.

Bongaarts, J. (2016). Africa's unique fertility transition. Population and Development Review, 1-20. https:// doi.org/10.1111/j.1728-4457.2016.00164.x.

Box-Steffensmeier, J. M., \& Zorn, C. (2002). Duration models for repeated events. The Journal of Politics, 64(4), 1069-1094.

Cameron, A. C., \& Trivedi, P. K. (2009). Microeconometrics using Stata. Stata Press.

Castro-Martín, T., \& Juarez, F. (1995). The impact of women's education on fertility in Latin America: Searching for explanations. International Family Planning Perspectives, 21(2), 52-57+80. https://doi.org/ 10.2307/2133523. 
Chattopadhyay, A., White, M. J., \& Debpuur, C. (2006). Migrant fertility in Ghana: Selection versus adaptation and disruption as causal mechanisms. Population Studies, 60(2), 189-203. https://doi.org/10. $1080 / 00324720600646287$.

Choi, K. (2014). Fertility in the context of Mexican migration to the United States. Demographic Research, 30, 703-738. https://doi.org/10.4054/DemRes.2014.30.24.

Devolder, D., \& Bueno García, X. (2011). Interacciones entre fecundidad y migración. Un estudio de las personas nacidas en el extranjero y residentes en Cataluña en 2007. Documents d'Analisi Geografica, 57(3), 441-461.

FitzGerald, D. (2012). A comparativist manifesto for international migration studies. Ethnic and Racial Studies, 35(10), 1725-1740. https://doi.org/10.1080/01419870.2012.659269.

Frank, R., \& Heuveline, P. (2005). A crossover in Mexican and Mexican-American fertility rates: Evidence and explanations for an emerging paradox. Demographic Research, 12(4), 77-104. https://doi.org/10. 4054/DemRes.2005.12.4.

Goldstein, S., \& Goldstein, A. (1981). The impact of migration on fertility: An "own children" analysis for Thailand. Population Studies, 35(2), 265-284. https://doi.org/10.1080/00324728.1981.10404967.

González-Ferrer, A., Baizán, P., \& Beauchemin, C. (2012). Child-parent separations among Senegalese migrants to Europe: Migration strategies or cultural arrangements? The Annals of the American Academy of Political and Social Science, 643(1), 106-133. https://doi.org/10.1177/0002716212444846.

González-Ferrer, A., Baizán, P., Beauchemin, C., Kraus, E. K., Schoumaker, B., \& Black, R. (2014). Distance, transnational arrangements, and return decisions of Senegalese, Ghanaian, and Congolese migrants. International Migration Review, 48(4), 939-971. https://doi.org/10.1111/imre.12148.

González-Ferrer, A., Castro-Martín, T., Kraus, E. K., \& Eremenko, T. (2017). Childbearing patterns among immigrant women and their daughters in Spain: Over-adaptation or structural constraints. Demographic Research, 37, 599-634. https://doi.org/10.4054/DemRes.2017.37.19.

Guetto, R., \& Panichella, N. (2013). Geographical mobility and reproductive choices of Italian men. European Sociological Review, 29(2), 302-315. https://doi.org/10.1093/esr/jcr068.

Guveli, A., Ganzeboom, H. B. G., Platt, L., Nauck, B., Baykara-Krumme, H., Eroglu-Hawksworth, S., et al. (2016). Intergenerational consequences of migration. Socio-economic, family and cultural patterns of stability and change in Turkey and Europe. Hampshire: Palgrave. https://doi.org/10.1057/ 9781137501424.

Guveli, A., Ganzeboom, H. B. G., Baykara-Krumme, H., Platt, L., Eroğlu, Ș., Spierings, N., et al. (2017). 2, 000 families: Identifying the research potential of an origins-of-migration study. Ethnic and Racial Studies, 40(14), 2558-2576. https://doi.org/10.1080/01419870.2016.1234628.

Impicciatore, R., Gabrielli, G., \& Paterno, A. (2020). Migrants' fertility in Italy: A comparison between origin and destination. European Journal of Population, 36(4), 799-825. https://doi.org/10.1007/s10680-01909553-w.

Jejeebhoy, S. J. (1995). Women's education, autonomy, and reproductive behaviour: Experience from developing countries. Clarendon Press.

Krapf, S., \& Wolf, K. (2015). Persisting differences or adaptation to German fertility patterns? First and second birth behavior of the 1.5 and second generation Turkish migrants in Germany. Kölner Zeitschrift für Soziologie und Sozialpsychologie, 67(Supplement 1), 137-164. https://doi.org/10.1007/s11577-0150331-8.

Kraus, E. K. (2019). Family formation trajectories across borders: A sequence analysis approach to Senegalese migrants in Europe. Advances in Life Course Research, 42(100290). https://doi.org/10.1016/j.alcr.2019. 100290

Kulu, H. (2005). Migration and fertility: Competing hypotheses re-examined. European Journal of Population, 21(1), 51-87. https://doi.org/10.1007/s10680-005-3581-8.

Kulu, H., \& González-Ferrer, A. (2014). Family dynamics among immigrants and their descendants in Europe: Current research and opportunities. European Journal of Population, 30, 411-435. https://doi. org/10.1007/s10680-014-9322-0.

Lardoux, S., \& Van de Walle, E. (2003). Polygyny and fertility in rural Senegal. Population, 58(6), 717-744. https://doi.org/10.3917/popu.306.0807.

Lindstrom, D. P., \& Giorguli-Saucedo, S. (2002). The short- and long-term effects of U.S. migration experience on Mexican women's fertility. Social Forces, 80(4), 1341-1368. https://doi.org/10.1353/sof. 2002.0030 .

Lindstrom, D. P., \& Giorguli-Saucedo, S. (2007). The interrelationship between fertility, family maintenance, and Mexico-U.S. migration. Demographic Research, 17, 821-858. https://doi.org/10.4054/DemRes. 2007.17.28. 
Marchetta, F., \& Sahn, D. E. (2015). The role of education and family background in marriage, childbearing and labor market participation in Senegal. Economic Development and Cultural Change, 64(2), 369-403. https://doi.org/10.1086/683982.

Massey, D. S., \& Mullan, B. P. (1984). A demonstration of the effect of seasonal migration on fertility. Demography, 21(4), 501-517. https://doi.org/10.2307/2060912.

Milewski, N. (2007). First child of immigrant workers and their descendants in West Germany: Interrelation of events, disruption, or adaptation? Demographic Research, 17, 859-896. https://doi.org/10.4054/DemRes. 2007.17.29.

Milewski, N. (2010a). Fertility of immigrants: A two-generational approach in Germany. Springer. https:// doi.org/10.1007/978-3-642-03705-4.

Milewski, N. (2010b). Immigrant fertility in West Germany: Is there a socialization effect in transitions to second and third births? European Journal of Population, 26(3), 297-323. https://doi.org/10.1007/ s10680-010-9211-0.

Milewski, N., \& Mussino, E. (2018). Editorial on the Special Issue "New aspects on migrant populations in Europe: Norms, attitudes and intentions in fertility and family planning.". Comparative Population Studies, 43(2018), 371-397. https://doi.org/10.12765/CPoS-2019-10en.

Mondain, N., Randall, S., \& Diagne, A. (2009). Assessing the Effects of Out-Migration on Those Left Behind in Senegal: Local Family Dynamics Between Change and Continuity. In XXVI International Population Conference (pp. 1-24). Marrakech.

Mulder, C. H., \& Wagner, M. (1993). Migration and marriage in the life course: A method for studying synchronized events. European Journal of Population, 9(1), 55-76. https://doi.org/10.1007/BF01267901.

Nedoluzhko, L., \& Agadjanian, V. (2010). Marriage, childbearing, and migration in Kyrgyzstan: Exploring interdependencies. Demographic Research, 22(7), 159-188. https://doi.org/10.4054/DemRes.2010.22.7.

Nedoluzhko, L., \& Andersson, G. (2007). Migration and first-time parenthood. Evidence from Kyrgyzstan. Demographic Research, 17(25), 741-774. https://doi.org/10.4054/DemRes.2007.17.25.

Parrado, E. A. (2011). How high is Hispanic/Mexican fertility in the United States? Immigration and tempo considerations. Demography, 48(3), 1059-1080. https://doi.org/10.1007/s13524-011-0045-0.

Ribe, H., \& Schultz, T. P. (1980). Migrant and native fertility in Colombia in 1973: Are migrants selected according to their reproductive preferences? Center Discussion Paper (No. 355).

Sargent, C., \& Cordell, D. (2003). Polygamy, disrupted reproduction, and the state: Malian migrants in Paris, France. Social Science and Medicine, 56(9), 1961-1972. https://doi.org/10.1016/S0277-9536(02)00216-2.

Schoumaker, B. (2004). Poverty and Fertility in Sub-Saharan Africa. Evidence from 25 countries. In Annual Meeting Population Association of America. https://doi.org/10.1017/CBO9781107415324.004

Schoumaker, B. (2019). Stalls in fertility transitions in sub-Saharan Africa: Revisiting the evidence. Studies in Family Planning, 50(3), 257-278. https://doi.org/10.1111/sifp.12098.

Schoumaker, B., \& Mezger, C. (2013). Sampling and computation weights in the MAFE Surveys. MAFE Methodological Note 6. INED. Retrieved January 31, 2021, from http://mafeproject.site.ined.fr/en/ methodo/methodological_notes/. Accessed 31 Jan 2021.

Shaw, W. (2007). Migration in Africa: A review of the economic literature on international migration in 10 countries (No. 43096). Development Prospects Group (DECPG). Retrieved January 31, 2021, from http://documents.worldbank.org/curated/en/2007/04/9243069/migration-africa-review-economicliterature-international-migration-10-countries. Accessed 31 Jan 2021.

Toma, S., \& Vause, S. (2013). On their own? A study of independent versus partner-related migration from the Democratic Republic of the Congo and Senegal. Journal of Intercultural Studies, 34(5), 533-552. https://doi.org/10.1080/07256868.2013.827832.

Toulemon, L. (2004). Fertility among immigrant women: new data, new approach. Population and Societies (Vol. 400). Retrieved January 31, 2021, from https://www.ined.fr/en/publications/editions/populationand-societies/fertility-among-immigrant-women-new-data-a-new-approach-en/. Accessed 31 Jan 2021.

van Dalen, H. P., Groenewold, G., \& Schoorl, J. J. (2005). Out of Africa: What drives the pressure to emigrate ? Journal of Population Economics, 18(4), 741-778. https://doi.org/10.1007/s00148-005-0003-5.

Vives, L., \& Vazquez Silva, I. (2016). Senegalese migration to Spain: transnational mothering practices. Journal of Ethnic and Migration Studies, https://doi.org/10.1080/1369183X.2016. 1186531.

Weinberger, M. B. (1987). The relationship between women's education and fertility: Selected findings from the World Fertility Surveys. International Family Planning Perspectives, 13(2), 35-46. https://doi.org/10. 2307/2947826.

Wolf, K. (2016). Marriage migration versus family reunification: How does the marriage and migration history affect the timing of first and second childbirth among Turkish immigrants 
in Germany? European Journal of Population, 32(5), 731-759. https://doi.org/10.1007/s10680016-9402-4.

Wolf, K., \& Mulder, C. H. (2018). Comparing the fertility of Ghanaian migrants in Europe with non-migrants in Ghana. Population, Space and Place,, 1-14. https://doi.org/10.1002/psp.2171.

World Bank. (2016). Migration and Remittances Factbook 2016. Washington, DC: World Bank. https://doi. org/10.1596/978-1-4648-0319-2.

Publisher's Note Springer Nature remains neutral with regard to jurisdictional claims in published maps and institutional affiliations. 